\title{
Gains to Bidder Firms Revisited: Domestic and Foreign Acquisitions in Canada
}

\author{
B. Espen Eckbo and Karin S. Thorburn*
}

\begin{abstract}
We present large sample evidence on the performance of domestic and U.S. (foreign) bidder firms acquiring Canadian targets. Domestic bidders earn significantly positive average announcement period abnormal returns, while U.S. bidder returns are indistinguishable from zero. Measures of pre- and post-acquisition abnormal accounting performance are also consistent with a superior domestic bidder performance. Domestic bidder announcement returns are, on average, greatest for offers involving stock payment and for the bidders with the smallest equity size relative to the target. Neither direct foreign investment controls, horizontal product market relationships, nor acquisition propensities explain why domestic bidders outperform their U.S. competitors.
\end{abstract}

\section{Introduction}

The proposition that a competitive market for corporate control effectively limits managerial divergence from shareholder wealth maximization implies that corporate takeovers are beneficial to shareholders of both firms involved in the transaction. However, while there is substantial evidence that shareholders of target firms, on average, realize large capital gains from corporate takeovers, the evidence on the profitability of takeovers for shareholders of bidder firms is mixed. Studies measuring abnormal stock price behavior around takeover events in the U.S. report average bidder firm performance that ranges from significantly positive in all-cash tender offers and horizontal mergers in the 1960s, to significantly negative in all-stock exchange mergers in the 1980s. Gains to bidders are generally found to be lower the greater the degree of observed competition for the target, whether from incumbent management or from rival bids. ${ }^{1}$ Furthermore, there is some evidence, particularly from studies examining corporate earnings, of a declining average bidder firm performance during the two- to five-year period

\footnotetext{
${ }^{*}$ Both authors, Amos Tuck School of Business Administration, Dartmouth College, Hanover, NH 03755. The authors are grateful for comments from Jonathan Karpoff, Øyvind Norli, Antonio Mello, and, especially, Paul Malatesta (the editor).

${ }^{1}$ See Jensen and Ruback (1983), Roll (1986), and Jarrell, Brickley, and Netter (1988) for extensive reviews of the evidence prior to 1988. More recent large sample evidence, see, e.g., Jarrell and Poulsen (1989), Loderer and Martin (1990), Schwert (1996), and Betton and Eckbo (1999).
} 
following merger announcements, which some authors argue should be attributed to the merger itself. ${ }^{2}$

While the empirical evidence is consistent with the proposition that competition among bidder firms grants most (if not all) of the rents from merger activity to target shareholders, it is also widely recognized that standard event-study methods tend to produce attenuated estimates of the total returns to bidder firms. This attenuation bias arises when public knowledge of the acquiring firm's prior merger activity leads to partial anticipation of future merger bids. Furthermore, when the target firm is small relative to the bidder, which is typical in studies sampling U.S. mergers, ${ }^{3}$ the power of the event-study methodology to register a given dollar gain is also relatively weak. Third, some takeover announcements have a high ex ante probability of triggering negative regulatory response or target management resistance. In the presence of such triggering events, the abnormal return at the initial acquisition announcement understates the total gains from a successful takeover.

As a result of these econometric difficulties, the question of the true magnitude of the gains to bidder firms remains an important, but largely unresolved empirical issue. We address this issue using a sample exceeding 1,800 domestic and foreign (all U.S.) successful acquisitions in Canada during the 1964-1983 period, prior to the introduction of substantive Canadian antitrust laws governing acquisitions. This sample presents an interesting laboratory for examining the performance of two distinct groups of bidders (foreign and domestic) operating in the same (Canadian) corporate control market, and it increases our knowledge of the general performance of U.S. bidder firms. Also, comparisons of the performance of the two sets of bidders, to a great extent, control for changes over time in the underlying structure of the corporate control market. This is relevant in terms of separating, e.g., the effect of bidder size (which varies across the two bidder groups) from the effect of increased competition in the takeover market (which affects both bidder groups equally). In studies of U.S. domestic acquisitions, it has been shown that bidder gains are largest in the 1960s and for the smallest bidder firms (e.g., Jarrell and Poulsen (1989) and Loderer and Martin (1990)), but it is not clear whether size per se or the generally less competitive acquisition market in the 1960s is the main explanation for the positive bidder returns during this time period. Competition in the U.S. market for corporate control generally increased in the 1970s with the introduction of mandatory disclosure rules and a minimum (20-day) waiting period for public tender offers as well as with the emergence of investment bank brokered takeover deals. ${ }^{4}$

We begin by reporting new evidence that successful domestic bidders, on average, earn significantly positive abnormal stock returns during the month of the first press announcement of the acquisition as well as over the two-day announcement period itself. This finding is robust with respect to alternative estimation procedures, and it is also, to some extent, supported by performance measures

\footnotetext{
${ }^{2}$ See, e.g., Ravenscraft and Scherer (1987), (1989).

${ }^{3}$ In the "Large Merger Series" of the Federal Trade Commission's Statistical Report on Mergers and Acquisitions, a typical sample source prior to 1985, the bidder firm is, on average, more than 10 times the size of the target (measured by the value of total equity).

${ }^{4} \mathrm{Jarrell}$ and Bradley (1980) and Eckbo and Langohr (1989) examine the effects of the introduction of disclosure rules on takeover premiums.
} 
based on accounting returns. In contrast, the average performance of U.S. bidders in Canada is indistinguishable from zero and significantly lower than the average performance of domestic bidders.

The paper discusses several potential explanations for the superior announcement returns of domestic bidders. First, we present new evidence on the effects of foreign direct investment controls in effect during the second half of our sample period. After 1972, foreign bidders in our sample were required to seek prior government approval before acquiring Canadian target firms. This approval procedure imposes costs on foreign bidders if it delays the acquisition process or reduces the foreign bidder's bargaining power with the target firm. Interestingly, we show that Canadian bidders also outperform U.S. foreign bidders in the sample period before the foreign review process existed, and that foreign bidders exempted from the review process earn insignificant abnormal returns as well. Thus, the foreign direct investment review procedure does not explain our finding of superior performance of domestic acquirors.

Second, it is possible that domestic bidders, perhaps due to a superior knowledge of Canadian markets, are in a better position than foreign bidders to exploit economic synergies following the takeover. Determining the source of synergy gains requires data on acquisition-induced changes in the firms' organizational structures, financing, and production/investment strategies, which are generally unavailable. However, an examination of horizontal vs. conglomerate acquisitions fails to support the hypothesis that the superior domestic bidder performance is limited to horizontal cases.

Third, we stratify our sample according to the payment method in the acquisition (all-cash, all-stock, or a mix of cash and stock). As reviewed by Hirshleifer (1995), a number of theories suggest that the bidder's choice of payment method reflects private information about the bidder's own stand-alone value or the value of the target's resources under the bidder's control. The evidence discussed here suggests that the valuation impact of the payment method is significantly different in Canada than in the U.S. In particular, all-stock offers (as well as mixed cash-stock bids) generate significantly positive average announcement effects in Canada, which contrasts with the significantly negative market reaction documented by Travlos (1987) for all-stock mergers in the U.S. As reviewed by Eckbo and Masulis (1995), there is substantial evidence that U.S. equity markets are characterized by adverse selection, which tends to cause a negative market reaction to the average equity issue. Moreover, there is much less evidence of a similar negative market reaction to equity issues internationally, including Canada. Thus, the superior domestic bidder performance possibly reflects a lower degree of adverse selection associated with the implicit equity issue in a Canadian domestic all-stock acquisition.

Fourth, we discuss issues related to relative size and partial anticipation of acquisition activity on our performance estimates. We show that the smallest Canadian bidders have the greatest average announcement returns. With the average U.S. bidder being eight times the size of the average domestic bidder, the insignificant abnormal returns to U.S. bidders are, in part, a reflection of relatively low precision in the abnormal return estimates for relatively large firms. Finally, we document a surprisingly similar acquisition frequency in the samples 
of domestic and foreign bidders. Moreover, following Malatesta and Thompson (1985), (1986), we perform structural tests for evidence of partial anticipation effects in the data. However, we find no support for the hypothesis that an attenuation bias due to partial anticipation of acquisition activity helps explain the relatively poor U.S. bidder performance in Canada.

The rest of the paper is organized as follows. Section II describes the data selection procedure and provides evidence on the sample-wide average profitability of bidder firms using both abnormal stock returns and abnormal earnings. Section III analyzes whether foreign investment controls, industry competition, and the payment method explain the superior performance by domestic bidders. A discussion of potential statistical effects of acquisition frequency and relative bidder size on the estimates of abnormal stock returns is given in Section IV, while Section V concludes the paper.

\section{Average Gains to Domestic and Foreign Bidders}

In this section, we present estimates of average monthly and daily abnormal stock price performance around the acquisition announcement, as well as annual abnormal earnings. To gauge the sensitivity of the conclusions to the method of estimation, we show results using both percentage returns and dollar values, and different estimation periods relative to (before and after) the event, as well as alternative specifications of the return-generating process.

\section{A. Sample Selection}

Our sample of domestic acquisitions is compiled by Eckbo (1986), while the foreign acquisitions sampled here are from the Merger Register of the Canadian Department of Consumer and Corporate Affairs (which is also the original data source for the sample of domestic cases in Eckbo (1986)). The Merger Register contains a total of 9,294 merger and acquisition bids announced between January 1945 and December 1983, of which 7,559 were announced after January 1, 1964. The Register records all mergers in industries subject to the $1910 \mathrm{Com}-$ bines Investigation Act, given the merger is announced in the news media, including newspapers, trade journals, and business magazines in Canada, the U.S., and Britain.

The following characterize the sample selection:

i) the merger bid occurs between January 1964 and December 1982, is successful (i.e., accepted by target shareholders), and the date of the acquisition's first press announcement is listed in the Merger Register;

ii) either the target firm is listed on the Toronto Stock Exchange (TSE) or the bidder firm is listed on the TSE or on the New York Stock Exchange (NYSE), and there is sufficient (as defined below) stock return data to perform the event study analysis.

Hostile takeovers were almost non-existent during the sample period, and none of the sample acquisitions elicited a hostile reaction by target management. The sample period ends prior to the introduction of civil antitrust laws governing cor- 
porate combinations in Canada. During the sample period, neither domestic nor U.S. bidders faced a threat of antitrust interference in the Canadian corporate control market.

For TSE-listed firms, stock return data are taken from the University of Laval monthly returns tape and the University of Western Ontario daily returns tape. Stock return data for NYSE-listed bidders are from the University of Chicago CRSP files. As Table 1 shows, of the population of 7,559 acquisition bids reported in the Merger Register over the sample period, a total of 1,846 acquisitions are included in the sample. Of the target firms in these acquisitions, all are Canadian firms, and 345 are listed on the TSE. Moreover, there are 394 NYSE-listed (foreign) and 1,261 TSE-listed (domestic) bidders in the sample.

\section{TABLE 1}

Annual Number of Domestic and Foreign Acquisitions in the Population and in the Sample, 1964-1983

\begin{tabular}{|c|c|c|c|c|c|}
\hline \multirow[b]{2}{*}{$\begin{array}{c}\text { Year of } \\
\text { Acquisition } \\
\text { Announcement }\end{array}$} & \multirow[b]{2}{*}{$\begin{array}{l}\text { Acquisitions } \\
\text { in } \\
\text { Population }^{\mathrm{a}}\end{array}$} & \multicolumn{4}{|c|}{ Acquisitions in Sample ${ }^{b}$} \\
\hline & & Total & $\begin{array}{c}\text { TSE-Listed } \\
\text { Bidders }\end{array}$ & $\begin{array}{l}\text { TSE-Listed } \\
\text { Targets }^{c}\end{array}$ & $\begin{array}{c}\text { NYSE-Listed } \\
\text { Bidders }\end{array}$ \\
\hline 1964 & 197 & 54 & 40 & 4 & 14 \\
\hline 1965 & 224 & 57 & 41 & 5 & 14 \\
\hline 1966 & 196 & 42 & 34 & 5 & 7 \\
\hline 1967 & 212 & 62 & 40 & 10 & 18 \\
\hline 1968 & 378 & 128 & 81 & 18 & 40 \\
\hline 1969 & 471 & 113 & 87 & 14 & 21 \\
\hline 1970 & 409 & 102 & 74 & 9 & 23 \\
\hline 1971 & 380 & 114 & 91 & 16 & 15 \\
\hline 1972 & 428 & 140 & 112 & 20 & 16 \\
\hline 1973 & 354 & 143 & 105 & 29 & 21 \\
\hline 1974 & 277 & 106 & 86 & 19 & 9 \\
\hline 1975 & 265 & 98 & 67 & 22 & 21 \\
\hline 1976 & 316 & 103 & 69 & 30 & 12 \\
\hline 1977 & 394 & 145 & 75 & 47 & 41 \\
\hline 1978 & 448 & 41 & 21 & 8 & 16 \\
\hline 1979 & 510 & 106 & 55 & 26 & 32 \\
\hline 1980 & 415 & 81 & 56 & 17 & 20 \\
\hline 1981 & 498 & 95 & 68 & 19 & 15 \\
\hline 1982 & 573 & 77 & 29 & 16 & 37 \\
\hline 1983 & 614 & 39 & 30 & 11 & 2 \\
\hline $1964-1983$ & 7,559 & 1,846 & 1,261 & 345 & 394 \\
\hline
\end{tabular}

a The population is the Merger Register, compiled annually by Consumer and Corporate Affairs Canada, which covers reported mergers and acquisitions in industries subject to the Combines Investigation Act. The Merger Register contains a total of 9,294 cases from January 1945-December 1983.

${ }^{\mathrm{b}}$ The sample is drawn from the Merger Register from 1964-1983 and requires that, at the time of the merger, either the target firm was listed on the Toronto Stock Exchange (TSE) or the bidder was listed on the TSE or the New York Stock Exchange (NYSE). Furthermore, a case was excluded if the Merger Register did not give the day of the press announcement, and if the firm did not satisfy the minimum data requirement for estimating abnormal stock returns, as described in the text.

${ }^{c}$ Of the 345 TSE-listed targets, 166 were targets of TSE-listed bidder firms and 48 were targets of NYSElisted bidder firms. The remaining 131 targets were acquired by bidders whose shares were not publicly traded.

\section{B. Average Abnormal Stock Returns}

Table 2 and Figure 1 show monthly abnormal stock returns to the TSE- and NYSE-listed bidder firms and the TSE-listed target firms during the 25-month 
period -12 through 12 relative to the month of the first press announcement of the acquisition. The abnormal returns are computed using the market model in excess return form,

$$
r_{j t}-r_{f t}=\alpha_{j}+\beta_{j}\left(r_{m t}-r_{f t}\right)+\epsilon_{j t}
$$

where $r_{j t}$ is the continuously compounded rate of return on security $j$ over month $t$, $r_{f t}$ is the continuously compounded rate of return on (U.S. or Canadian) Treasury bills that mature at the end of month $t,{ }^{5} r_{m t}$ is the continuously compounded rate of return on the value-weighted portfolio of all stocks traded in the market over month $t,{ }^{6}$ and $\epsilon_{j t}$ is assumed to be a normally, identically distributed, serially uncorrelated zero mean disturbance term.

To account for the possibility that the merger event itself changes the regression constant $\alpha_{j}$ and/or the systematic risk $\beta_{j}$, two sets of coefficients are estimated under this procedure, one based on data before the merger event and one based on data after the event. The first set of coefficients, $\left(\alpha_{j}^{b}, \beta_{j}^{b}\right)$, is estimated using a maximum of 48 and a minimum of 24 monthly returns drawn from relative month -60 through month -13 . The second set of coefficients, $\left(\alpha_{j}^{a}, \beta_{j}^{a}\right)$, is estimated using a maximum of 48 and a minimum of 24 monthly returns drawn from relative month 13 through month 60. Month zero is the month of the first press announcement of the merger. Abnormal return during event month $\tau$ is then computed as

$$
\widehat{\gamma}_{j \tau}= \begin{cases}r_{j \tau}-\left[r_{f \tau}+\widehat{\alpha}_{j}^{b}+\widehat{\beta}_{j}^{b}\left(r_{m \tau}-r_{f \tau}\right)\right] & \text { for }-12 \leq \tau \leq 0 \\ r_{j \tau}-\left[r_{f \tau}+\widehat{\alpha}_{j}^{a}+\widehat{\beta}_{j}^{a}\left(r_{m \tau}-r_{f \tau}\right)\right] & \text { for } 1 \leq \tau \leq 12\end{cases}
$$

where superscript carets denote OLS estimates. Thus, in Table 2, a pre-event benchmark is used to estimate abnormal returns up through month zero, while a post-event benchmark is used to estimate performance after month zero. If a firm has insufficient data to perform the regression in the "after" period, the "before" coefficients $\left(\alpha_{j}^{b}, \beta_{j}^{b}\right)$ are used to predict returns up through month two. Similarly, when there is insufficient data to perform the regression in the "before" period, the "after" coefficients $\left(\alpha_{j}^{a}, \beta_{j}^{a}\right)$ are used to predict backward through month -2 .

Table 2 reports the average abnormal return for month $\tau$ relative to the event $\left(\left(1 / N_{\tau}\right) \sum_{j=1}^{N_{\tau}} \widehat{\gamma}_{j \tau}\right.$, where $N_{\tau}$ is the number of firms in the sample having valid abnormal returns in month $\tau$ ), and the cumulative average abnormal return. A $Z$-statistic, which in large samples has a standard normal distribution provided the merger events are independent, is used to infer statistical significance. The $Z$-statistic for the average abnormal return is computed as

$$
Z_{\tau} \equiv \frac{1}{\sqrt{N}_{\tau}} \sum_{j=1}^{N_{\tau}} \frac{\widehat{\gamma}_{j \tau}}{\widehat{\sigma}_{\gamma_{j}}} \stackrel{\mathrm{a}}{\sim} N(0,1) .
$$

\footnotetext{
${ }^{5}$ The U.S. risk-free rate was derived from the T-bills on the CRSP bond tape, while the Canadian rate was derived using information published by the Bank of Canada.

${ }^{6}$ The U.S. market is provided by CRSP, while the Canadian market was derived using the firms on the Laval tape.
} 


\section{TABLE 2}

\section{Monthly Average Abnormal Stock Returns to Canadian Targets and Domestic and Foreign (U.S.) Bidders}

(Total Sample, 1964-1983)

Percent average monthly abnormal return over the year prior to and following the month of the first press announcement of the acquisition (month 0 ) where the abnormal return to firm $j$ over month $\tau$ is computed as the excess return market model prediction error,

$$
\widehat{\gamma}_{j \tau}= \begin{cases}r_{j \tau}-\left[r_{f \tau}+\widehat{\alpha}_{j}^{b}+\widehat{\beta}_{j}^{b}\left(r_{m \tau}-r_{f \tau}\right)\right] & \text { for }-12 \leq \tau \leq 0 \\ r_{j \tau}-\left[r_{f r}+\widehat{\alpha}_{j}^{a}+\widehat{\beta}_{j}^{a}\left(\widehat{r}_{m \tau}-r_{f r}\right)\right] & \text { for } 1 \leq \tau \leq 12\end{cases}
$$

where $r_{j \tau}, r_{f \tau}$, and $r_{m \tau}$ are the continuously compounded rates of return to firm $j$, the risk-free asset, and the value-weighted market index over event month $\tau$, and the market model coefficients are estimated using a minimum of 24 and a maximum of 48 months from the before-event period -60 through -13 $\left(\widehat{\alpha}_{j}^{b}, \widehat{\beta}_{j}^{b}\right)$ or the after-event period 13 through $60\left(\widehat{\alpha}_{j}^{a}, \widehat{\beta}_{j}^{a}\right) .^{a}$

\begin{tabular}{|c|c|c|c|c|c|c|c|c|c|}
\hline \multirow[b]{2}{*}{$\begin{array}{l}\text { Event } \\
\text { Month }\end{array}$} & \multicolumn{3}{|c|}{$\begin{array}{c}\text { Bidders on the TSE } \\
\qquad(N=1261)\end{array}$} & \multicolumn{3}{|c|}{$\begin{array}{l}\text { Bidders on the NYSE } \\
\qquad(N=390)\end{array}$} & \multicolumn{3}{|c|}{$\begin{array}{l}\text { Targets on the } \text { TSE }^{d} \\
\qquad(N=332)\end{array}$} \\
\hline & $\begin{array}{c}\text { Average } \\
\widehat{\gamma}_{\tau} \\
(\%) \\
\end{array}$ & $Z_{\tau}$ & $\begin{array}{c}\text { Cumulative } \\
\text { Average } \\
(\%) \\
\end{array}$ & $\begin{array}{c}\text { Average } \\
\widehat{\gamma}_{\tau} \\
(\%) \\
\end{array}$ & $Z_{\tau}$ & $\begin{array}{c}\text { Cumulative } \\
\text { Average } \\
(\%) \\
\end{array}$ & $\begin{array}{c}\text { Average } \\
\hat{\gamma}_{\tau} \\
(\%) \\
\end{array}$ & $Z_{\tau}$ & $\begin{array}{c}\text { Cumulative } \\
\text { Average } \\
(\%) \\
\end{array}$ \\
\hline-12 & -0.45 & -0.92 & -0.45 & -0.46 & -1.26 & -0.46 & -0.41 & -0.81 & -0.41 \\
\hline-11 & 0.07 & 1.39 & -0.38 & 0.79 & 1.84 & 0.33 & 0.09 & 0.36 & -0.32 \\
\hline-10 & 0.61 & 2.57 & 0.23 & 0.11 & 0.56 & 0.43 & 0.49 & 1.30 & 0.18 \\
\hline-9 & 0.19 & 1.71 & 0.42 & 0.76 & 2.04 & 1.20 & -0.27 & -0.29 & -0.09 \\
\hline-8 & -0.41 & -0.95 & 0.01 & -0.61 & -1.97 & 0.58 & 0.74 & 0.78 & 0.66 \\
\hline-7 & -0.12 & 0.04 & -0.11 & 0.41 & 0.79 & 0.99 & -0.02 & -1.19 & 0.64 \\
\hline-6 & 0.04 & 1.01 & -0.07 & 0.21 & 0.78 & 1.20 & -0.15 & 0.05 & 0.49 \\
\hline-5 & 0.63 & 2.07 & 0.55 & -0.22 & -0.52 & 0.98 & -0.22 & -0.09 & 0.27 \\
\hline-4 & 0.66 & 3.17 & 1.21 & -0.71 & -1.83 & 0.26 & 1.03 & 2.64 & 1.29 \\
\hline-3 & 0.28 & 0.54 & 1.49 & -0.13 & 0.38 & 0.38 & 0.14 & 2.78 & 2.77 \\
\hline-2 & 0.43 & 2.09 & 1.93 & 0.39 & 1.53 & 0.52 & 1.18 & 2.46 & 3.95 \\
\hline-1 & 0.44 & 1.96 & 2.37 & -0.11 & -0.40 & 0.41 & 3.86 & 7.75 & 7.81 \\
\hline 0 & 1.27 & 4.51 & 3.64 & -0.19 & -0.79 & 0.22 & 3.59 & 6.25 & 11.40 \\
\hline 1 & -0.18 & -0.03 & 3.45 & -0.40 & -1.19 & -0.17 & -0.88 & -1.59 & 10.51 \\
\hline 2 & 0.12 & 0.83 & 3.57 & 0.17 & 0.39 & -0.00 & 0.24 & 0.14 & 10.75 \\
\hline 3 & 0.26 & 0.59 & 3.82 & -0.49 & -1.05 & -0.49 & 2.70 & 2.05 & 13.45 \\
\hline 4 & 0.79 & 2.94 & 4.62 & -0.06 & -0.12 & -0.55 & -1.28 & -0.79 & 12.17 \\
\hline 5 & -0.45 & -0.91 & 4.17 & -0.13 & 0.47 & -0.68 & -0.40 & -1.25 & 11.78 \\
\hline 6 & -0.31 & -1.00 & 3.86 & -0.46 & -0.37 & -1.13 & 0.08 & 0.66 & 11.86 \\
\hline 7 & 0.03 & 0.73 & 3.89 & -0.72 & -1.72 & -1.85 & -1.42 & -1.65 & 10.45 \\
\hline 8 & 0.47 & 1.78 & 4.36 & 0.07 & 0.27 & -1.79 & 0.03 & -0.27 & 10.48 \\
\hline 9 & -0.25 & -0.79 & 4.12 & -0.59 & -1.07 & -2.38 & 0.73 & 1.14 & 11.21 \\
\hline 10 & -0.44 & -0.57 & 3.67 & -0.67 & -1.16 & -3.05 & 0.25 & 0.99 & 11.46 \\
\hline 11 & -0.77 & -1.37 & 2.90 & -0.05 & -0.04 & -3.09 & 0.21 & 0.73 & 11.67 \\
\hline 12 & 0.11 & 0.61 & 3.01 & -0.40 & -0.20 & -3.49 & -1.80 & -2.21 & 9.87 \\
\hline $\begin{array}{l}{[-12,-1]} \\
{[1,12]}\end{array}$ & & $\begin{array}{l}4.24 \\
0.81\end{array}$ & $\begin{array}{r}2.37 \\
-0.63\end{array}$ & & $\begin{array}{r}0.56 \\
-1.53\end{array}$ & $\begin{array}{r}0.41 \\
-3.72\end{array}$ & & $\begin{array}{r}4.55 \\
-0.59\end{array}$ & $\begin{array}{r}7.81 \\
-1.53\end{array}$ \\
\hline
\end{tabular}

a The reported $Z_{\tau}$-value of the average abnormal return is distributed approximately standard normal and is given by $Z_{\tau} \equiv\left(1 / \sqrt{N}_{\tau}\right) \sum \widehat{\gamma}_{j \tau} / \widehat{\sigma}_{\gamma_{j}}$, where $\widehat{\sigma}_{\gamma_{\tau}}$ is the estimated standard error of the abnormal return $\gamma_{j \tau}$ and $N_{\tau}$ is the total number of cases with valid (non-missing) abnormal returns in period $\tau$.

${ }^{b}$ The average market value of total equity in month -12 is CAD $\$ 69$ million.

${ }^{c}$ The average market value of total equity in month -12 is US $\$ 450$ million.

d The average market value of total equity in month -12 is $C A D \$ 53$ million. 


\section{FIGURE 1}

Percent Monthly Cumulative Average Abnormal Stock Returns to Canadian Targets and Domestic and Foreign (U.S.) Bidders 1964-1983

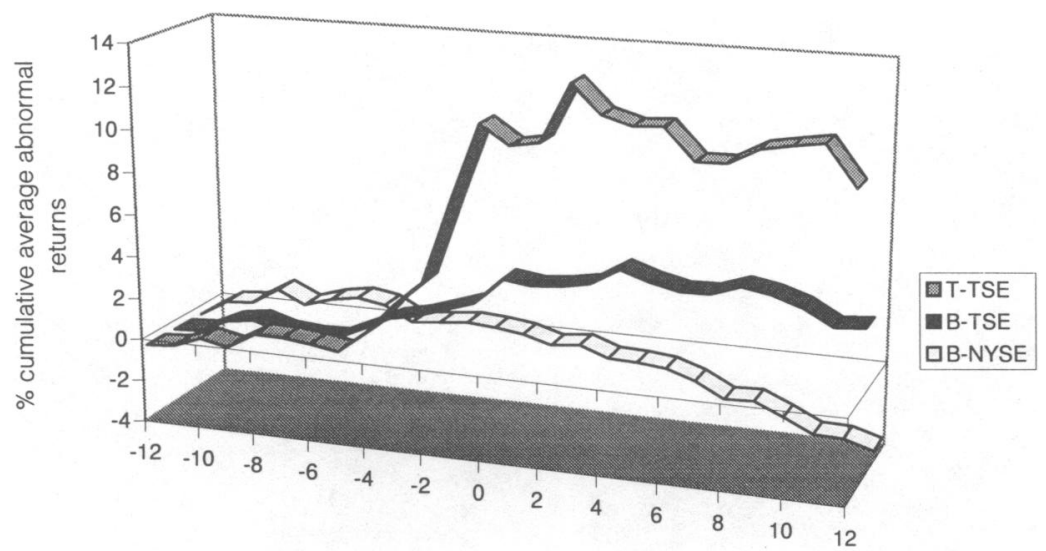

Month relative to first announcement of acquisition

The sample contains 332 target firms listed on the Toronto Stock Exchange (T-TSE), 1,261 bidder firms listed on the Toronto Stock Exchange (B-TSE), and 390 bidder firms listed on the New York Stock Exchange (B-NYSE). All bids are for Canadian targets. Abnormal returns are computed using market model residuals (equation (2)), and the estimation period is five years or 60 monthly return observations. See Table 2 for details.

As in Theil ((1971), pp. 122-123), an unbiased estimate of the standard deviation $\sigma_{\gamma_{j}}$ is given by

$$
\widehat{\sigma}_{\gamma_{j}} \equiv \widehat{\sigma}_{\epsilon_{j}}\left[R_{m \tau}\left(R_{m}^{\prime} R_{m}\right)^{-1} R_{m \tau}^{\prime}+1\right]^{1 / 2}
$$

where $R_{m \tau}$ is the vector of observations on the independent variables in period $\tau, R_{m}$ is the matrix of observations on the independent variables used in the estimation period, and $\widehat{\sigma}_{\epsilon_{j}}$ is the OLS estimate of the standard error of the regression disturbances over the estimation period. ${ }^{7}$

A visual impression of the cumulative average abnormal return for each subsample is presented in Figure 1. The 332 targets listed on the TSE earn, on average, cumulative abnormal returns of $11.40 \%$ during the 12 months prior to and including the month of the acquisition announcement, with a significant $3.59 \%$ during the announcement month itself $(Z=6.25)$. The 1261 domestic bidder firms

\footnotetext{
${ }^{7}$ In the bottom two rows of Table 2, the $Z$-value for the average abnormal returns cumulated over $L$ event months $\tau_{1}$ through $\tau_{2}$ is given by

$$
Z_{\tau_{1} \tau_{2}} \equiv \frac{1}{\sqrt{L}} \sum_{\tau=\tau_{1}}^{\tau_{2}} Z_{\tau} .
$$

This Z-statistic presumes that the monthly average abnormal returns are serially independent as well.
} 
listed on the TSE earn, on average, $3.64 \%$ during the period from month -12 through month 0 , with a significant $1.27 \%$ in the announcement month $(Z=4.51)$. Figure 1 also confirms the positive average share price development for domestic bidders up through the announcement month. In contrast, the 390 foreign bidders listed in the NYSE show no significant average abnormal returns during any of the event periods. In particular, during the year following the acquisition, cumulative abnormal returns to NYSE bidders average $-3.72 \%$ with an insignificant $Z$-value of -1.53 .

Table 3 provides information on the robustness of the announcement period abnormal return estimates from Table 2 with respect to the choice of estimation period and the use of monthly vs. daily stock returns. In Table 3, and throughout the rest of the paper, the month zero abnormal return is estimated by adding a dummy variable $d_{j t}$ to equation (1), where $d_{j t}$ takes on a value of one in the announcement month and zero otherwise,

$$
r_{j t}-r_{f t}=\alpha_{j}+\beta_{j}\left(r_{m t}-r_{f t}\right)+\gamma_{j} d_{j t}+\epsilon_{j t}
$$

In this model, the event parameter $\gamma_{j}$ directly isolates the component of the firm's return that is due to the acquisition. Since there is only one acquisition event per regression, the event dummy $d_{j t}$ and the excess return on the market are uncorrelated. Consequently, the estimate of $\gamma_{j}$ from equation (3) is identical to that obtained from a two-step procedure such as in equation (2). ${ }^{8}$ The month zero estimates reported in Panels A and B of Table 3 differ from the corresponding month zero estimate in Table 2 only because the estimation of $\gamma_{j}$ in Table 3 does not mix data from the pre- and post-event period.

Panel A of Table 3 reports the average estimate of $\gamma_{j}$ when the estimation period is month -60 through -13 . The average announcement month abnormal return to TSE-listed bidders is $1.13 \%$ or $\$ 6.89$ million, both of which are statistically significant at the $1 \%$ level or higher. Using a post-event estimation period (Panel B) yields a slightly higher event parameter: on average, $1.81 \%$ or $\$ 9.48$ million. The abnormal returns to NYSE-listed bidders remain insignificant regardless of the estimation. Finally, Panel $\mathrm{C}$ of Table 3 reports abnormal return estimates using daily return data. In these regressions, the risk-free rate is excluded and the event-dummy $d_{j t}$ takes on a value of one for the two-day announcement period (day -1 and day 0 ). As shown, TSE-listed bidders realize a statistically significant average two-day announcement period abnormal return $(2 \widehat{\gamma})$ of $0.81 \%$, or $\$ 0.64$ million, with $Z$-values of 4.23 and 3.40 , respectively. The two-day announcement period abnormal return for NYSE-listed bidders is an insignificant $0.08 \%$. In sum, the finding of significantly positive average abnormal stock returns to TSE-listed bidders and insignificant gains to NYSE-listed bidders in Canada appears robust.

\footnotetext{
${ }^{8}$ The estimate of the standard error of $\gamma_{j n}$ is now provided directly by the OLS regression routine.
} 


\section{TABLE 3}

\section{Announcement-Induced Average Abnormal Returns to Domestic and Foreign Bidders under Alternative Estimation Procedures}

(Total Sample 1964-1983)

OLS estimates of the abnormal return coefficient $\gamma_{j}$ in the excess return market model,

$$
r_{j t}-r_{f t}=\alpha_{j}+\beta_{j}\left(r_{m t}-r_{f t}\right)+\gamma_{j} d_{j t}+\epsilon_{j t},
$$

where $r_{j t}, r_{f t}$, and $r_{m t}$ are the continuously compounded rates of return to security $j$, the risk-free asset, and the value-weighted market index over period $t$; $d_{j t}$ takes on a value of one in the event period and zero otherwise; and $\epsilon_{j t}$ is a zero mean disturbance term. The event period is the month of the acquisition announcement when using monthly stock returns and the day of the announcement and the previous day when using daily stock returns. When using daily stock returns (Panel $C$ ), the risk-free rate $r_{f t}$ is excluded from the regression. Furthermore, with daily data, the total event period abnormal return is $2 \gamma_{j}$, which is the number reported in the table.

\begin{tabular}{|c|c|c|c|c|c|c|}
\hline \multirow[b]{2}{*}{ Sample } & \multirow{2}{*}{$\begin{array}{l}\text { Sample } \\
\text { Size }(N) \\
\end{array}$} & \multirow{2}{*}{$\begin{array}{l}\text { Average } \\
\widehat{\gamma}_{j}^{\mathrm{a}}\end{array}$} & \multirow{2}{*}{$\begin{array}{l}\text { Percent } \\
\text { Positive } \\
\end{array}$} & \multicolumn{2}{|c|}{$\begin{array}{c}\text { Percent } \\
\text { Significant }(5 \%)\end{array}$} & \multirow{2}{*}{$\begin{array}{c}\begin{array}{c}Z- \\
\text { Value }\end{array} \\
\end{array}$} \\
\hline & & & & Positive & Negative & \\
\hline \multicolumn{7}{|c|}{ Panel A. Monthly Returns and Pre-Event Estimation Period (Month -60 through Month -13$)^{\mathrm{C}}$} \\
\hline Bidders on TSE & $\begin{array}{l}1099 \\
1097\end{array}$ & $\begin{array}{c}1.13 \% \\
\$ 6.89 \text { million }\end{array}$ & $\begin{array}{l}52.0 \\
56.0\end{array}$ & $\begin{array}{r}5.5 \\
12.0\end{array}$ & $\begin{array}{l}2.5 \\
6.8\end{array}$ & $\begin{array}{r}3.30 \\
10.10\end{array}$ \\
\hline Bidders on NYSE & $\begin{array}{l}371 \\
367\end{array}$ & $\begin{array}{c}0.16 \% \\
\$-6.81 \text { million }\end{array}$ & $\begin{array}{l}50.0 \\
54.0\end{array}$ & $\begin{array}{l}2.6 \\
9.0\end{array}$ & $\begin{array}{l}2.7 \\
8.2\end{array}$ & $\begin{array}{l}0.12 \\
0.11\end{array}$ \\
\hline \multicolumn{7}{|c|}{ Panel B. Monthly Returns and Post-Event Estimation Period (Month 13 through Month 60) ${ }^{\mathrm{c}}$} \\
\hline Bidders on TSE & $\begin{array}{l}1227 \\
1225\end{array}$ & $\begin{array}{c}1.81 \% \\
\$ 9.48 \text { million }\end{array}$ & $\begin{array}{l}55.2 \\
52.0\end{array}$ & $\begin{array}{l}5.3 \\
7.3\end{array}$ & $\begin{array}{l}2.5 \\
3.4\end{array}$ & $\begin{array}{l}5.75 \\
7.17\end{array}$ \\
\hline Bidders on NYSE & $\begin{array}{l}343 \\
340\end{array}$ & $\begin{array}{c}0.87 \% \\
\$-0.23 \text { million }\end{array}$ & $\begin{array}{l}55.1 \\
59.4\end{array}$ & $\begin{array}{l}2.3 \\
3.2\end{array}$ & $\begin{array}{l}1.2 \\
3.5\end{array}$ & $\begin{array}{l}2.01 \\
1.87\end{array}$ \\
\hline \multicolumn{7}{|c|}{ Panel C. Daily Returns and Post-Event Estimation Period (Day 1 through Day 480) ${ }^{\mathrm{d}}$} \\
\hline Bidders on TSE & $\begin{array}{l}464 \\
430\end{array}$ & $\begin{array}{c}0.81 \% \\
\$ 0.64 \text { million }\end{array}$ & $\begin{array}{l}53.7 \\
53.3\end{array}$ & $\begin{array}{l}7.1 \\
6.1\end{array}$ & $\begin{array}{l}2.2 \\
3.0\end{array}$ & $\begin{array}{l}4.23 \\
3.40\end{array}$ \\
\hline Bidders on NYSE & 385 & $0.08 \%$ & 50.4 & 3.9 & 2.6 & 0.57 \\
\hline
\end{tabular}

${ }^{a}$ Abnormal dollar returns are obtained by estimating $\gamma_{j}$ after premultiplying the terms $\left(r_{j t}-r_{f t}\right)$ and $\left(r_{m t}-r_{f t}\right)$ with $V_{j, t-1}$, the prior end-of-period market value of total equity.

${ }^{\mathrm{b}} Z=(1 / \sqrt{N}) \sum_{j} \widehat{\gamma}_{j} / \widehat{\sigma}_{\gamma_{j}} \stackrel{\text { as }}{\sim} N(0,1)$, where $N$ is the sample size and $\widehat{\sigma}_{\gamma_{j}}$ is the estimated standard error of $\gamma_{j}$.

${ }^{\mathrm{c}}$ To be included, a firm must have a minimum of 24 valid returns over the 48 -month period as well as a valid return in month zero. The dummy variable takes on a value of one in event month zero. The 12 months $(-12$ through -1$)$ in the before-event estimation and (one through 12) in the after-event estimation procedure are excluded.

d To be included, a firm must have 150 valid return observations drawn over the 480 trading-day estimation period.

\section{Average Abnormal Changes in Earnings (EBIT)}

Table 4 reports estimates of average abnormal earnings changes around acquisition events using the following conditional market model,

$$
\Delta E_{j t}=\alpha_{e j}+\beta_{e j} \Delta E_{m t}+\gamma_{e j n} d_{j t n}+\epsilon_{e j t}
$$

where $\Delta E_{j t}$ is firm $j$ 's change in earnings before interest and taxes (EBIT) recorded by Compustat during year $t$ (where information on EBIT for Canadian bidders is found in the Canadian section of the U.S. Compustat tape as well as in a separate Compustat file for Canadian firms), $E_{m t}$ is the equal-weighted average EBIT across all Compustat firms in year $t$ (where $E_{m t}$ is constructed using U.S. companies only for the U.S. bidders in the sample, and Canadian firms only for the 
domestic bidders in the sample), $\Delta E_{m t}$ is the change in $E_{m t}$ during year $t$, and $\epsilon_{e j t}$ is a mean zero error term.

\section{TABLE 4}

Average Annual Abnormal Changes in Earnings to Canadian Targets and Domestic and Foreign (U.S.) Bidders in the Year Prior to through Three Years following the Year of the Acquisition (1964-1983)

OLS estimates of the abnormal earnings coefficients $\gamma_{e j n}$ in the following market model,

$$
\Delta E_{j t}=\alpha_{e j}+\beta_{e j} \Delta E_{m t}+\gamma_{e j n} d_{j t n}+\epsilon_{e j t},
$$

where $\Delta E_{j t}$ is firm $j$ 's change in earnings before interest and taxes (EBIT) over year $t, E_{m t}$ is the equal-weighted average EBIT across all firms on the S\&P Compustat tape in year $t, \Delta E_{m t}$ is the change over year $t$ in $E_{m t}$, and $\epsilon_{e j t}$ is a mean zero error term. The estimation period is year -6 through year -2 (where year zero is the year of the merger) plus the single year $n$ used to define the dummy variable $d_{j t n}, n=-1,0,1,2,3$, which takes on a value of one in year $n$ and zero otherwise. Thus, the five $\gamma_{\text {ein }}$-coefficients are estimated using five separate regressions, always using the pre-acquisition period -6 through -2 as the comparison period. The market model is estimated using the first difference (as above), and the rate of change, $100 \times\left(E_{j t}-E_{j, t-1}\right) / E_{j, t-1}$, in earnings from period $t-1$ to $t$. Data on EBIT for the Canadian firms in the sample are drawn from the Canadian firms on the U.S. Compustat file and from a separate Compustat file for Canadian firms. The market EBIT is constructed using U.S. companies only for the sample of bidders listed on the NYSE, and Canadian companies only when regressing the model using Canadian firms. The regression is run only once for a given firm over a given estimation period; i.e., the estimated value of, e.g., $\gamma_{j 0}$ for a given firm, in principle, covers the cumulative effect of all mergers undertaken by that firm over that year. When the regression uses the rate of change in earnings, data from year -7 is added in order to create an observation for year -6 . Earnings data for target firms end in year zero.

\begin{tabular}{|c|c|c|c|c|c|c|c|}
\hline \multirow[b]{2}{*}{ Unit } & \multirow[b]{2}{*}{$\widehat{\alpha_{e}}$} & \multirow[b]{2}{*}{$\widehat{\beta_{e}}$} & \multicolumn{5}{|c|}{ Average $\widehat{\gamma}_{e j n}\left(Z\right.$-Value and Percent Positive in Parentheses) ${ }^{a}$} \\
\hline & & & Year $n=-1$ & Year $n=0$ & Year $n=1$ & Year $n=2$ & Year $n=3$ \\
\hline \multicolumn{8}{|c|}{ Panel A. Bidder Firms Listed on the TSE $(N=303)$} \\
\hline$\$$ million & $\begin{array}{c}0.55 \\
(18.20 ; 72.3)\end{array}$ & $\begin{array}{c}0.82 \\
(16.04 ; 67.3)\end{array}$ & $\begin{array}{c}3.92 \\
(20.27 ; 61.7)\end{array}$ & $\begin{array}{c}1.65 \\
(14.34 ; 62.0)\end{array}$ & $\begin{array}{c}1.67 \\
(11.98 ; 60.0)\end{array}$ & $\begin{array}{c}0.30 \\
(6.32 ; 55.3)\end{array}$ & $\begin{array}{c}3.98 \\
(13.01 ; 56.0)\end{array}$ \\
\hline$\%$ & $\begin{array}{c}6.76 \\
(20.71 ; 75.2)\end{array}$ & $\begin{array}{c}-1.48 \\
(-10.94 ; 62.0)\end{array}$ & $\begin{array}{c}12.30 \\
(17.32 ; 53.1)\end{array}$ & $\begin{array}{c}21.37 \\
(20.34 ; 53.5)\end{array}$ & $\begin{array}{c}6.06 \\
(7.10 ; 50.0)\end{array}$ & $\begin{array}{c}6.45 \\
(6.80 ; 49.7)\end{array}$ & $\begin{array}{c}-13.34 \\
(-11.56 ; 41.3)\end{array}$ \\
\hline \multicolumn{8}{|c|}{ Panel B. Bidder Firms Listed on the NYSE $(N=215)$} \\
\hline$\$$ million & $\begin{array}{c}7.87 \\
(16.85 ; 75.8)\end{array}$ & $\begin{array}{c}1.29 \\
(13.79 ; 74.9)\end{array}$ & $\begin{array}{c}-12.72 \\
(-11.58 ; 56.7)\end{array}$ & $\begin{array}{c}2.07 \\
(5.32 ; 55.4)\end{array}$ & $\begin{array}{c}-0.25 \\
(1.63 ; 54.0)\end{array}$ & $\begin{array}{c}-4.65 \\
(-3.06 ; 53.0)\end{array}$ & $\begin{array}{c}12.43 \\
(7.16 ; 56.2)\end{array}$ \\
\hline $\begin{array}{l}\% \\
(\%)\end{array}$ & $\begin{array}{c}11.93 \\
(18.08 ; 76.3)\end{array}$ & $\begin{array}{c}1.86 \\
(10.38 ; 67.4)\end{array}$ & $\begin{array}{c}-8.23 \\
(-3.55 ; 45.6)\end{array}$ & $\begin{array}{c}-17.56 \\
(-4.50 ; 41.5)\end{array}$ & $\begin{array}{c}-19.09 \\
(-4.02 ; 39.5)\end{array}$ & $\begin{array}{c}-25.45 \\
(-5.30 ; 37.4)\end{array}$ & $\begin{array}{c}-10.15 \\
(-2.01 ; 37.0)\end{array}$ \\
\hline \multicolumn{8}{|c|}{ Panel C. Target Firms Listed on the TSE $(N=79)$} \\
\hline$\$$ million & $\begin{array}{c}-1.09 \\
(2.21 ; 55.7)\end{array}$ & $\begin{array}{c}0.39 \\
(6.42 ; 69.6)\end{array}$ & $\begin{array}{c}-3.24 \\
(-0.31 ; 54.4)\end{array}$ & $\begin{array}{c}8.32 \\
(4.10 ; 62.0)\end{array}$ & & & \\
\hline$\%$ & $\begin{array}{c}1.09 \\
(3.97 ; 64.6)\end{array}$ & $\begin{array}{c}0.10 \\
(4.50 ; 62.0)\end{array}$ & $\begin{array}{c}56.32 \\
(3.66 ; 55.7)\end{array}$ & $\begin{array}{c}49.76 \\
(4.06 ; 61.0)\end{array}$ & & & \\
\hline
\end{tabular}

$a_{Z}=(1 \sqrt{N}) \sum_{j} \widehat{\gamma}_{e j} / \widehat{\sigma}_{\gamma_{e j}} \stackrel{\text { as }}{\sim} N(0,1)$, where $N$ is the sample size and $\widehat{\sigma}_{\gamma_{e j}}$ is the estimated standard error of $\gamma_{e j}$. The table uses the sample of bidders and targets with a complete set of earnings data available on the S\&P Compustat files for years -7 through year zero. Some firms have missing data for one or more of the event years one through three, thus the sample sizes underlying the estimation of the event parameter for these years are somewhat smaller.

The estimation period is year -6 through year -2 (where year zero is the year of the acquisition) plus the single year $n$ used to define the dummy variable $d_{j t n}, n=-1,0,1,2,3$, which takes on a value of one in year $n$ and zero otherwise. Thus, to avoid overparameterization, the five $\gamma_{e j n}$ coefficients are estimated using five separate regressions, always using the pre-acquisition period -6 through -2 as the comparison period. The market model is estimated using the first difference (as above), and the rate of change, $100 \times\left(E_{j t}-E_{j, t-1}\right) / E_{j, t-1}$, in earnings from period $t-1$ to $t$. When the regression uses the rate of change in earnings, data from year -7 are added to create an observation for year -6 . Earnings data for target firms end in year zero. The regression is run only once for a given firm over a given estimation period; i.e., the estimated value of, e.g., $\gamma_{j 0}$ covers the 
cumulative effect of all acquisitions undertaken by firm $j$ over that year. The table uses the sample of bidders and targets with a complete set of earnings data available on the S\&P Compustat files for years -7 through year zero. Some firms have missing data for one or more of the event years one through three, thus the sample sizes underlying the estimation of the event parameter for these years are somewhat smaller.

As Table 4 shows, the estimated values of $\beta$ are all highly significant, indicating that individual firm earnings are highly correlated with the general earnings of the market. Moreover, there is a significant difference in the average abnormal earnings change coefficients $\widehat{\gamma}_{e}$ for years $n=-1$ and $n=0$ for TSE-listed and NYSE-listed bidders when expressed in percentage terms. For example, TSElisted bidders experience significantly positive abnormal earnings changes in year -1 and year zero of $12.30 \%$ and $21.37 \%$. The corresponding abnormal earnings changes for NYSE-listed bidders is a significant $-8.23 \%$ and $-17.56 \%$, respectively. When measuring abnormal earnings in dollar terms, however, TSE-listed bidders outperform NYSE-listed bidders in year -1 but not in the announcement year. From Panel C, we also see that TSE-listed targets, on average, experience large positive abnormal earnings changes over years -1 and zero of $56.32 \%$ and $49.76 \%$, respectively, with a significantly positive dollar value abnormal earnings change in year zero. Thus, domestic acquisitions tend to occur after a period of superior earnings performance, while foreign bidders tend to make a bid after a period of abnormally low (negative) changes in earnings.

Turning to the post-acquisition event parameters in Table $4,(n=1,2,3)$, the results show that the generally positive pre-acquisition abnormal earnings performance of TSE-listed bidders is typically followed by a continued positive drift except in year +3 . NYSE-listed bidders tend to continue the negative preacquisition abnormal earnings performance throughout the post-acquisition event period, with the exception of year three when the average dollar value abnormal earnings are a significant $\$ 12.43$ million.

Overall, the results indicate that TSE-listed bidders show superior earnings performance as well as superior stock price performance relative to NYSE-listed bidders in Canada. We now turn to an examination of various possible explanations for this differential performance. For this purpose, the analysis focuses in particular on the announcement month abnormal return estimated from equation (3).

\section{Economic Hypotheses for the Superior Domestic Bidder Gains}

In this section, we examine three factors that potentially drive our evidence of superior gains to domestic bidders. The first is the effect of foreign direct investment controls. As described below, in the second half of our sample period, the "playing field" was not entirely even for foreign and domestic bidders acquiring Canadian targets, potentially increasing acquisition costs for foreign bidders. The second factor concerns a potential advantage to domestic bidders in terms of horizontal product market relationships with the respective targets. The third factor concerns the valuation effects of stock as a payment method in acquisitions. 
Most of the sample transactions are stock deals (the bidder and target exchange shares), and there is substantial extant evidence that bidder gains in U.S. acquisitions are lower in all-stock than in all-cash transactions.

\section{A. Foreign Direct Investment Controls}

Between 1974 and 1984 (i.e., during the latter half of our sample period), acquisitions of Canadian firms by foreign bidders were regulated under the 1973 Foreign Investment Review (FIR) Act, enforced by the Foreign Investment Review Agency (FIRA). Under Section 2(2) of the FIR Act, a foreign bidder was required to disclose plans to expand, modernize, relocate or close existing target facilities, and the extent of Canadian participation on both ownership and control of the merged firm. On the basis of the disclosed information, FIRA would determine (possibly after negotiations with the bidder) whether the acquisitions would provide significant benefits to Canada.

The FIR Act was in part motivated by the Gray Report (1972), which lists several potentially undesirable impacts of foreign direct investments in Canada, allegedly restricting Canadian sovereignty over its industrial policy. For a vivid account of the events that led to the FIR Act, and the international (in particular, the U.S.) reaction to the resulting unilateral trade restriction, see Clarkson (1982). FIRA considers Canadian participation a key consideration in determining significant benefits for industries already dominated by foreign ownership. A further positive consideration is avoidance of bankruptcy. Small acquisitions (i.e., targets with less than $\$ 250,000$ in assets, less than $\$ 3,000,000$ in revenues, and fewer than 100 employees) do not have to meet the significant benefit test, only a "no detriment" test. The power of FIRA to review foreign acquisitions was eventually curtailed in 1985.

According to FIRA annual reports, approximately 2,100 foreign acquisition attempts were reviewed between 1974 and 1984, with an approval rate of $90 \%$. Since the source of our merger sample is the Merger Register, there are no disapproved FIRA cases in our data base. Of the 394 foreign acquisitions in the sample, 172 were reviewed (and approved) by FIRA while the remaining 222 were not subject to review (200 cases took place before the 1974 introduction of the FIR Act while 22 cases were exempted in 1976 and 1977). The 172 approved FIRA cases are distributed evenly during the 1974-1983 period.

The hypothesis of interest is that compliance with the requirements under the FIR Act transferred some or all of the expected rents from the acquisition to target shareholders, or to other Canadian interests protected by FIRA in its bilateral negotiations with the bidder firm. In testing this hypothesis, recall that, since our sample is restricted to foreign bidders listed on the NYSE, we tend to pick up the largest foreign acquisitions (measured in terms of the asset size of the bidder) reviewed by FIRA. The largest foreign acquisitions tend to be the most politically controversial, which further strengthens FIRA's bargaining power. Thus, if FIRA has succeeded in extracting a significant portion of the gains to successful foreign bidders, it is more likely reflected in the sample used here than in a randomly selected sample of FIRA cases. Thus, if anything, our sample is biased toward 
finding evidence that supports the conclusion that FIRA has successfully extracted rents from foreign acquirors.

Table 5 provides some direct evidence on this issue. NYSE-listed bidder firms earn negative but insignificant abnormal stock returns regardless of whether or not the case was reviewed by FIRA. Moreover, TSE-listed bidders continue to show significantly positive announcement month abnormal returns both before and during FIRA's review activity. In sum, there is no apparent effect of FIRA's activities on the average U.S. bidder in our sample. In particular, the results reject the hypothesis that FIRA's review activity has made the NYSE-listed bidders in Canada worse off. Notice also that TSE-listed bidders earn lower abnormal returns during the 13-month period -12 through zero during the period with FIRA review ( $-2.16 \%$ vs. $4.38 \%$ before 1974). Similarly, there is no evidence of an increase in the gains to TSE-listed targets during the period with FIRA reviews. Thus, if FIRA succeeded in transferring rents from the NYSE-listed foreign bidders to Canadian interests, there is no evidence in Table 5 that domestic bidders or targets benefited from such a transfer.

The proposition that FIRA effectively helps target shareholders extract a larger share of the total merger gains can also be examined using samples of target firms in foreign acquisitions before and after FIRA was established. Only 10 of the 172 mergers reviewed by FIRA involve a TSE-listed target firm present in the data base. Although not included in Table 5, the cumulative average abnormal return for these 10 targets turns out to be $13.3 \%$ over the $-12,0$ interval, compared to $10.3 \%$ for the remaining targets involved in acquisitions not reviewed by FIRA. We cannot reject the hypothesis that these two cumulative average abnormal returns are equal. Overall, there is no evidence that the enforcement of the FIR Act has affected either the level or distribution of merger gains between the two parties directly involved in the transaction.

\section{B. Industry Competition}

Intuitively, synergistic gains are more likely to occur when there is a horizontal relationship between the bidder and target firms. Thus, it is possible that domestic bidders tend to outperform foreign acquirors because purely domestic acquisitions tend to involve more closely related bidder and target firms. Table 6 sheds some light on this issue by showing average abnormal returns for horizontal vs. non-horizontal acquisitions in our sample for which product market information could be identified from Moody's manuals or the Standard \& Poor's directories. A relationship is defined as horizontal if the target and bidder firms operate in the same major two-digit or four-digit Standard Industrial Classification (SIC) industry, respectively. Table 5 shows there is little indication that a horizontal relationship between the bidder and the target increases the average gains to bidders. ${ }^{9}$ The largest, significant abnormal returns occur in the "two-

\footnotetext{
${ }^{9}$ While not shown in Table 6 , a similar conclusion emerges when examining abnormal returns to targets.
} 
TABLE 5

Average Abnormal Returns to Canadian Targets and Domestic and Foreign (U.S.) Bidders before and during FIRA's Merger Review Activitya

OLS estimates of the abnormal return coefficient $\gamma_{j}$ in the excess return market model,

$$
r_{j t}-r_{f t}=\alpha_{j}+\beta_{j}\left(r_{m t}-r_{f t}\right)+\gamma_{j} d_{j t}+\epsilon_{j t},
$$

where $r_{j t}, r_{f t}$, and $r_{m t}$ are the continuously compounded rates of return to security $j$, the risk-free asset, and the value-weighted market index over period $t ; d_{j t}$ takes on a value of one in the event period and zero otherwise; and $\epsilon_{i t}$ is a zero mean disturbance term. The estimation period is month -60 through month -13 , while the event period is either the 13-month period month -12 through month zero (the announcement month) or the announcement month itself.

\begin{tabular}{|c|c|c|c|c|c|c|}
\hline Sample & $\begin{array}{l}\text { Sample } \\
\text { Size }(N) \\
\end{array}$ & $\begin{array}{l}\text { Event } \\
\text { Period }\end{array}$ & \multicolumn{2}{|c|}{$\begin{array}{c}\text { Average }^{\mathrm{b}} \\
\widehat{\gamma}_{j} \\
\end{array}$} & $\begin{array}{l}\text { Percent } \\
\text { Positive } \\
\end{array}$ & $\begin{array}{c}Z- \\
\text { Value }^{c} \\
\end{array}$ \\
\hline \multicolumn{7}{|c|}{ Panel A. Foreign Bidders Listed on the NYSE } \\
\hline $\begin{array}{l}\text { NYSE bidders not } \\
\text { reviewed by FIRA }\end{array}$ & 222 & $\begin{array}{l}\text { Month } 0 \text { only } \\
\text { Month }-12 \text { through } 0\end{array}$ & \multicolumn{2}{|c|}{$\begin{array}{l}-0.76 \%(\$-2.5 \text { million }) \\
-0.84 \%(\$-8.2 \text { million })\end{array}$} & $\begin{array}{l}51.1 \\
45.8\end{array}$ & $\begin{array}{l}-1.59 \\
-0.37\end{array}$ \\
\hline $\begin{array}{l}\text { NYSE bidders } \\
\text { reviewed by FIRA }\end{array}$ & 172 & $\begin{array}{l}\text { Month } 0 \text { only } \\
\text { Month }-12 \text { through } 0\end{array}$ & \multicolumn{2}{|c|}{$\begin{array}{r}-0.73 \%(\$-8.8 \text { million }) \\
0.29 \%(\$-1.1 \text { million })\end{array}$} & $\begin{array}{l}43.3 \\
47.7\end{array}$ & $\begin{array}{r}-1.64 \\
0.03\end{array}$ \\
\hline \multicolumn{7}{|c|}{ Panel B. Domestic Bidders Listed on the TSE } \\
\hline $\begin{array}{l}\text { TSE bidders before } \\
\text { FIRA (1964-1973) }\end{array}$ & 586 & $\begin{array}{l}\text { Month } 0 \text { only } \\
\text { Month }-12 \text { through } 0\end{array}$ & $\begin{array}{l}0.72 \%(\$ \\
4.38 \%(\$\end{array}$ & $\begin{array}{l}0.3 \text { million) } \\
4.5 \text { million) }\end{array}$ & $\begin{array}{l}53.0 \\
51.2\end{array}$ & $\begin{array}{l}2.10 \\
3.71\end{array}$ \\
\hline $\begin{array}{l}\text { TSE bidders during } \\
\text { FIRA (1974-1983) }\end{array}$ & 513 & $\begin{array}{l}\text { Month } 0 \text { only } \\
\text { Month }-12 \text { through } 0\end{array}$ & $\begin{array}{l}0.80 \%(\$ \\
-2.16(\$\end{array}$ & $\begin{array}{l}1.2 \text { million) } \\
3.6 \text { million) }\end{array}$ & $\begin{array}{l}52.6 \\
47.5\end{array}$ & $\begin{array}{r}2.07 \\
-0.34\end{array}$ \\
\hline \multicolumn{7}{|c|}{ Panel C. Domestic Targets Listed on the TSE } \\
\hline $\begin{array}{l}\text { TSE targets before } \\
\text { FIRA (1964-1973) }\end{array}$ & 151 & $\begin{array}{l}\text { Month } 0 \text { only } \\
\text { Month }-12 \text { through } 0\end{array}$ & $\begin{array}{r}6.17 \%(\$ \\
15.27 \%(\$\end{array}$ & $\begin{array}{l}0.4 \text { million) } \\
2.3 \text { million) }\end{array}$ & $\begin{array}{l}58.9 \\
55.4\end{array}$ & $\begin{array}{l}6.46 \\
5.07\end{array}$ \\
\hline $\begin{array}{l}\text { TSE targets during } \\
\text { FIRA (1974-1983) }\end{array}$ & 262 & $\begin{array}{l}\text { Month } 0 \text { only } \\
\text { Month }-12 \text { through } 0\end{array}$ & $\begin{array}{l}2.35 \%(\$ \\
7.61 \%(\$\end{array}$ & $\begin{array}{l}0.6 \text { million) } \\
5.3 \text { million) }\end{array}$ & $\begin{array}{l}57.8 \\
55.0\end{array}$ & $\begin{array}{l}4.02 \\
3.51\end{array}$ \\
\hline
\end{tabular}

a case is classified as "reviewed by FIRA" according to information in FIRA annual reports. Of the 394 foreign bids in our sample, 172 were reviewed and approved by FIRA, while 222 were not subject to review. Of the 222 cases, 200 took place before the introduction of the FIR Act in 1974, and 22 cases were exempted from review in 1976 and 1977. From 1974-1983, FIRA reviewed a total of 2,127 cases of which 204 (or 10\%) were disapproved. Since our sample is restricted to successful acquisitions, there are no disapproved cases in our data base.

${ }^{\mathrm{b}}$ Abnormal dollar returns are obtained by estimating $\gamma_{j}$ after pre-multiplying the terms $\left(r_{j t}-r_{f t}\right)$ and $\left(r_{m t}-r_{f t}\right)$ with $V_{f, t-1}$, the prior end-of-period market value of total equity. To be included, a firm must have a minimum of 24 valid returns over the 48 -month period -60 through -13 . ${ }^{c} Z=(1 / \sqrt{N})$
of $\gamma_{j}$.

digit non-horizontal" category for TSE-listed bidders, while there is no evidence of significantly positive gains to NYSE-listed bidders, horizontal or otherwise. ${ }^{10}$

\section{The Payment Method}

Several studies report that takeover premiums and merger-induced abnormal returns are systematically related to the payment method. Huang and Walkling (1987), Franks, Harris, and Mayer (1988), and Eckbo and Langohr (1989) show that gains to target firms in the U.S., England, and France, respectively, are significantly higher in all-cash offers than in takeovers in which the bidder and target firms exchange common stock. Studying merger bids in the U.S., Travlos

\footnotetext{
${ }^{10}$ Eckbo (1992) examines the effect of merger announcements on the equity values of product market rivals of the target firms in Canadian and U.S. domestic horizontal mergers and rejects the hypothesis that merger gains are the result of increased market power.
} 


\section{TABLE 6}

\section{Average Abnormal Returns to Domestic (Canadian) and Foreign (U.S.) Bidders in Horizontal and Non-Horizontal Acquisitions (1964-1983)}

OLS estimates of the abnormal return coefficient $\gamma_{j}$ in the excess return market model,

$$
r_{j t}-r_{f t}=\alpha_{j}+\beta_{j}\left(r_{m t}-r_{f t}\right)+\gamma_{j} d_{j t}+\epsilon_{j t}
$$

where $r_{j t}, r_{f t}$, and $r_{m t}$ are the continuously compounded rates of return to security $j$, the risk-free asset, and the value-weighted market index over period $t ; d_{j t}$ takes on a value of one in month zero and zero otherwise; and $\epsilon_{j t}$ is a zero mean disturbance term. The estimation period is month 13 through month 60 , excluding months one through 12 . Total sample of bidder firms classified by whether or not the merging firms operate in the same two-digit Standard Industrial Classification (SIC) industry ("two-digit horizontal") or in the same four-digit SIC industry ("four-digit horizontal"). ${ }^{\text {a }}$

( $Z$-values and percent positive in parentheses)

\begin{tabular}{|c|c|c|c|c|c|c|}
\hline \multirow[b]{2}{*}{$\begin{array}{c}\text { Type of } \\
\text { Acquisition }\end{array}$} & \multicolumn{3}{|c|}{$\begin{array}{l}\text { Bidder Firms Listed } \\
\text { on the TSE }(N=491)\end{array}$} & \multicolumn{3}{|c|}{$\begin{array}{l}\text { Bidder Firms Listed } \\
\text { on the NYSE }(N=182)\end{array}$} \\
\hline & $\begin{array}{l}\text { No. of } \\
\text { Firms }\end{array}$ & $\begin{array}{c}\text { Average } \\
\widehat{\gamma}_{0} \\
(\%)\end{array}$ & $\begin{array}{c}\text { Average } \\
\widehat{\gamma}_{0} \\
(\$ \text { million })^{\mathrm{b}}\end{array}$ & $\begin{array}{l}\text { No. of } \\
\text { Firms }\end{array}$ & $\begin{array}{c}\text { Average } \\
\widehat{\gamma}_{0} \\
(\%)\end{array}$ & $\begin{array}{c}\text { Average } \\
\widehat{\gamma}_{0} \\
(\$ \text { million })^{\mathrm{b}}\end{array}$ \\
\hline $\begin{array}{l}\text { Two-digit } \\
\text { horizontal }\end{array}$ & 158 & $\begin{array}{c}1.14 \\
(1.37 ; 55.1)\end{array}$ & $\begin{array}{c}18.42 \\
(1.54 ; 51.3)\end{array}$ & 63 & $\begin{array}{c}1.11 \\
(1.09 ; 57.1)\end{array}$ & $\begin{array}{c}-22.33 \\
(0.67 ; 65.1)\end{array}$ \\
\hline $\begin{array}{l}\text { Four-digit } \\
\text { horizontal }\end{array}$ & 89 & $\begin{array}{c}1.31 \\
(0.92 ; 57.1)\end{array}$ & $\begin{array}{c}33.73 \\
(1.48 ; 52.4)\end{array}$ & 18 & $\begin{array}{c}0.26 \\
(-0.20 ; 44.4)\end{array}$ & $\begin{array}{c}-115.60 \\
(-2.16 ; 55.6)\end{array}$ \\
\hline $\begin{array}{l}\text { Two-digit } \\
\text { non-horizontal }\end{array}$ & 333 & $\begin{array}{c}1.94 \\
(2.84 ; 55.9)\end{array}$ & $\begin{array}{c}4.91 \\
(2.35 ; 52.9)\end{array}$ & 119 & $\begin{array}{c}0.57 \\
(1.07 ; 52.9)\end{array}$ & $\begin{array}{c}-1.51 \\
(0.87 ; 55.1)\end{array}$ \\
\hline
\end{tabular}

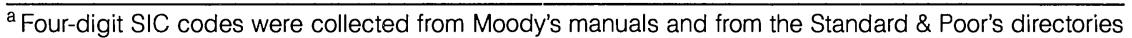
for as many firms as could be found. A given acquisition is included in this table only if at least one fourdigit SIC code could be identified for each of the bidder and target firms. $Z=(1 / \sqrt{N}) \sum_{j} \widehat{\gamma}_{j} / \widehat{\sigma}_{\gamma_{j}} \stackrel{\text { as }}{\sim}$ $N(0,1)$, where $N$ is the sample size and $\widehat{\sigma}_{\gamma_{j}}$ is the estimated standard error of $\gamma_{j}$.

${ }^{\mathrm{b}}$ The dollar value of the estimated $\gamma_{j}$ is obtained by running the regression after pre-multiplying the dependent variable and the market factor by $V_{j, t-1}$, the prior end-of-period market value of total equity.

(1987) reports significantly negative two-day announcement period average abnormal stock returns to bidder firms in all-stock mergers, while the corresponding bidder firm performance in all-cash mergers is zero or positive. Moreover, Eckbo, Giammarino, and Heinkel (1990) present evidence that bidder gains in Canada are, on average, greatest when the bidder offers a mix of cash and stock.

The literature focuses, in particular, on taxes and information asymmetries to explain these empirical regularities. The tax codes in the countries represented by the above studies generally award a tax-deferred status to a pure exchange merger while requiring capital gains taxes to be paid immediately in an all-cash purchase. ${ }^{11}$ Thus, it is frequently hypothesized that the bidder must raise the offer premium in an all-cash offer to compensate target shareholders for the tax penalty associated with this particular method of payment. However, while tax considerations are certain to play a role in the bidder's choice of payment method, tax arguments do not appear to explain the relatively large premium in all-cash offers. Furthermore, Franks, Harris, and Mayer (1988) report that a superior target performance in all-cash offers is found in U.K. takeovers that took place before the introduction of capital gains taxes on such transactions.

\footnotetext{
${ }^{11}$ The payment method may also dictate the bidder's accounting treatment of the acquisition, thus affecting depreciation tax shields and accounting-based managerial compensation schemes (see, e.g., Carleton, Guilkey, Harris, and Stewart (1983)). For a general discussion of tax arguments, see Gilson, Scholes, and Wolfson (1988).
} 
Asymmetric information also plays a role in the choice of the medium of exchange in takeovers. To illustrate, suppose the true bidder value is common knowledge while the true target value is private information (known by the target only). The bidder knows the distribution over possible target values including its maximum, $t^{*}$, and suppose the bidder's strategy is to bid $t^{*}$ to guarantee success. Then, if the bidder pays with cash, the expected value of the bid is

$$
t^{*}-E(t \mid \text { accept })>0
$$

which we label "the expected overpayment cost of cash." Alternatively, suppose the bidder offers payment in the form of securities in the combined firm (all-stock offer). Let $z^{*}$ denote the fraction of the equity in the combined firm offered to the target that guarantees target acceptance,

$$
z^{*}\left(b+t^{*}\right)=t^{*} \longrightarrow z^{*}=\frac{t^{*}}{b+t^{*}},
$$

where $b$ is the known bidder value. The expected value to the bidder of this allstock offer is

$$
\left.z^{*}[b+E(t \mid \text { accept })]-E(t \mid \text { accept })\right)=\frac{b\left(t^{*}-E(t \mid \text { accept })\right.}{b+t^{*}}>0
$$

which we label "the expected overpayment cost of stock." Comparing the two expected overpayment costs in (5) and (7), since $b /\left(b+t^{*}\right)<1$, the bidder strictly prefers securities to cash as the method of payment. Intuitively, while the value of a cash offer does not depend on the true value of the target ex post, payment in bidder shares forces the target to share in the overpayment cost ex post. Of course, if we allow the true value of the bidder to be private information as well (two-sided information asymmetry), then the above preference for a stock offer is reversed provided the bidder shares are sufficiently undervalued by the target. ${ }^{12}$ Extending this intuition, Eckbo, Giammarino, and Heinkel (1990) derive a fully separating equilibrium consistent with the use of a mix of cash and securities, and where the proportion of the total bid value paid in cash is a signal of the true bidder value. Thus, the difference between the average gains to bidders in the U.S. and Canadian samples studied here may to some extent reflect differences in the signaling effect of the payment method.

Table 7 shows the average abnormal returns to bidders across categories of payment methods for a subset of our domestic acquisitions. The abnormal return estimation follows our equation (3), i.e., $\gamma_{j}$ is the abnormal return parameter

\footnotetext{
${ }^{12}$ With two-sided information asymmetry, let $\widehat{b}$ denote target belief about bidder value. In this case, the all-stock offer $z^{*}$, which guarantees success, is given by $z^{*}\left(\widehat{b}+t^{*}\right)=t^{*}$, and the difference between the expected overpayment cost of an all-stock and an all-cash offer equals

$$
t^{*} \frac{(b-\widehat{b})-\left(t^{*}-E(t \mid \text { accept })\right)}{b+E(t \mid \text { accept })},
$$

which can be positive or negative depending on whether the target undervalues $(b-\widehat{b}>0)$ or overvalues $(b-\widehat{b}<0)$ the bidder shares. Hansen (1987), Fishman (1989), and Eckbo, Giammarino, and Heinkel (1990) all define various tradeoffs between expected overpayment costs, undervaluation costs, and, in the case of bids with a success-probability less than one, the cost of lost synergy gains, to derive signaling equilibria where the market reacts to the information concerning the bidders choice of payment method.
} 
for the announcement month. All-cash offers, on average, lead to an increase of $3.11 \%$ in the bidder's share value over the event month, which is marginally significant with a $Z$-value of 1.80 and with only $47.9 \%$ of the sample having positive abnormal return. The larger group of all-stock offers has a statistically significant average abnormal return of $2.99 \%$ ( $Z$-value $2.18,65 \%$ positive). Moreover, the average bidder presenting a mixed offer gains a highly significant $5.10 \%$ abnormal return over the announcement month ( $Z$-value of $4.61,64.9 \%$ positive). The hypothesis that the average abnormal return in mixed offers is the same as in the all-cash or all-stock offers is rejected at the $1 \%$ level of significance. ${ }^{13}$

\section{TABLE 7}

\section{Average Abnormal Returns to Domestic (Canadian) Bidders Classified by the Payment Method (1964-1983)}

OLS estimates of the abnormal return coefficient $\gamma_{j}$ in the excess return market model,

$$
r_{j t}-r_{f t}=\alpha_{j}+\beta_{j}\left(r_{m t}-r_{f t}\right)+\gamma_{j} d_{j t}+\epsilon_{j t},
$$

where $r_{j t}, r_{f t}$, and $r_{m t}$ are the continuously compounded rates of return to security $j$, the risk-free asset, and the value-weighted market index over period $t ; d_{j t}$ takes on a value of one in month zero and zero otherwise; and $\epsilon_{j t}$ is a zero mean disturbance term. The estimation period is month 13 through month 60 , plus month zero. Information on the payment method is from the Merger Register, the Financial Post data base, or the manuals of Moody's Corporation.

(Z-values and percent positive in parentheses) ${ }^{\mathrm{a}}$

\begin{tabular}{|c|c|c|c|}
\hline \multirow[b]{2}{*}{ Payment Method } & \multirow[b]{2}{*}{ Sample Size } & \multicolumn{2}{|c|}{ Average $\widehat{\gamma_{j}}$} \\
\hline & & $\%$ & $\$$ Million \\
\hline All-cash & $N=90$ & $\begin{array}{c}3.11 \\
(1.80 ; 47.9)\end{array}$ & $\begin{array}{c}1.17 \\
(1.93 ; 60.4)\end{array}$ \\
\hline All-stock & $N=268$ & $\begin{array}{c}2.99 \\
(2.18 ; 65.0)\end{array}$ & $\begin{array}{c}2.93 \\
(2.21 ; 61.7)\end{array}$ \\
\hline Cash and stock & $N=58$ & $\begin{array}{c}5.10 \\
(4.61 ; 64.9)\end{array}$ & $\begin{array}{c}5.21 \\
(3.72 ; 64.9)\end{array}$ \\
\hline
\end{tabular}

${ }^{a}$ Abnormal dollar returns are obtained by estimating $\gamma_{j}$ after pre-multiplying the terms $\left(r_{j t}-r_{f t}\right)$ and $\left(r_{m t}-r_{f t}\right)$ with $V_{j, t-1}$, the prior end-of-period market value of total equity. $Z=(1 / \sqrt{N}) \sum_{j}\left(\widehat{\gamma}_{j} / \widehat{\sigma}_{\gamma_{j}}\right) \stackrel{\text { as }}{\sim}$ $N(0,1)$, where $N$ is the sample size and $\widehat{\sigma}_{\gamma_{j}}$ is the OLS estimate of the standard deviation of $\gamma_{j}$.

While we do not have data on the payment method in the sample of foreign acquisitions, the results in Table 7 can be compared to extant evidence on the effect of the payment method on bidder gains in U.S. domestic takeovers. Travlos (1987) reports that average bidder returns in all-stock offers are small but negative, while average bidder returns in all-cash offers are positive. The negative impact of all-stock offers in the U.S. thus contrasts with the significantly positive effect of all-stock and mixed stock-cash offers reported in Table 7. One

\footnotetext{
${ }^{13}$ Using a subsample of the cases in Table 7, Eckbo, Giammarino, and Heinkel (1990) perform regression tests of the hypothesis that the incremental gain in mixed offers represents an average signaling gain or simply a larger average synergy revaluation in this particular offer category. Their model implies that the announcement effect (bidder abnormal return) is increasing and convex in the proportion of the bid that is paid in cash, i.e.,

$$
\gamma_{j}=h_{j}\left(\frac{c_{j}}{\bar{t}}\right), \quad h_{j}^{\prime}, h_{j}^{\prime \prime}>0,
$$

where $c_{j}$ is the cash payment, $\bar{t}$ is the average pre-bid target value, and the " $"$ " and " $/ \prime \prime$ " denote first and second derivatives, respectively. Using cross-sectional regressions, they find no support for convexity.
} 
potential explanation for this difference is that the equity issue implicit in a stock offer suffers from an adverse selection problem of the type analyzed in Myers and Majluf (1984), and that the potential for adverse selection is greater for U.S. than for Canadian domestic bidder firms. ${ }^{14}$ Adverse selection is a consequence of information asymmetry between the issuer and outside investors, and we expect merger negotiations to effectively resolve much of this asymmetry. Nevertheless, since the target is in Canada, it is possible that NYSE investors remain informationally disadvantaged relative to TSE investors when it comes to judging the true value of both the target and the bidder's offer.

\section{Econometric Hypotheses for the Superior Domestic Bidder Gains}

In this section, we explore hypotheses concerning the measurement of bidder gains using announcement period stock returns. The precision of the estimate of a given dollar gain is lower the greater the normal variation in the bidder's (dollar) equity value. There is also a risk that announcement returns provide attenuated estimates of the economic value of the merger. The central question is whether the superior domestic bidder performance is an artifact of the econometric methodology.

\section{A. Relative Size of Bidder}

Asquith, Bruner, and Mullins (1983) regress the merger-induced abnormal returns to bidder firms on the relative size of target to bidder and find a statistically significant, positive coefficient. This is consistent with a measurement problem for relatively large bidders: the greater the normal variation in the bidder's equity value, the more difficult it is to register a given bidder gain from the acquisition. Similarly, Loderer and Martin (1990) estimate cross-sectional models of bidder returns that indicate that bidder returns are significantly higher when the offer value exceeds $30 \%$ of the acquiring firm's equity value, and significantly lower when the market value of the bidder's equity exceeds $\$ 150$ million. They find evidence of significantly positive acquiring firm returns only in the smallest size category. Jarrell and Poulsen (1989) also find evidence that bidder abnormal returns tend to increase with the relative size of the target.

As shown earlier in Table 2, the average total equity value of the TSE-listed targets is approximately the same for both groups of bidders, while the total equity value of the average U.S. bidder is more than eight times the value of the average domestic bidder. Moreover, as shown in Table 8, of 1,226 TSE-listed bidders, 905 or $74 \%$ have an equity value of $\$ 100$ million or less while, of 341 NYSE-listed bidders, only 61 or $18 \%$ of the bidders fall in this size category. Since the average target size is similar across the domestic and foreign bidders, a ranking of the bidders on bidder size is highly correlated with a ranking on the relative size of the target. Since relatively few of the target firms have publicly traded equity, we focus in Table 8 on the total equity value of bidders to maximize sample size.

\footnotetext{
${ }^{14}$ Consistent with this view, Eckbo and Verma (1992) report less negative market reaction to seasoned equity offer announcements in Canada than in the U.S.
} 


\section{TABLE 8}

Average Monthly Abnormal Returns to Domestic and Foreign (U.S.) Bidders Classified by the Market Value of the Bidder's Total Equity (1964-1983)

OLS estimates of the abnormal return coefficient $\gamma$ in the excess return market model,

$$
r_{j t}-r_{f t}=a_{j}+\beta_{j}\left(r_{m t}-r_{f t}\right)+\gamma_{j} d_{j t}+\epsilon_{j t},
$$

where $r_{j t}, r_{f t}$, and $r_{m t}$ are the continuously compounded rates of return to security $j$, the risk-free asset, and the value-weighted market index over period $t ; d_{j t}$ takes on a value of one in the event period and zero otherwise; and $r_{j t}$ is a zero mean disturbance term. The estimation period is month +13 through month +60 , i.e., excluding months +1 through +12 . $V$ is the market value of total equity of the bidder firm in the month prior to the month of the acquisition announcement. ${ }^{a}$

( $Z$-values and percent positive in parentheses)

\begin{tabular}{|c|c|c|c|c|c|c|c|}
\hline \multicolumn{4}{|c|}{ 1,226 Bidder Firms Listed on the TSE } & \multicolumn{4}{|c|}{341 Bidder Firms Listed on the NYSE } \\
\hline $\begin{array}{c}\text { Range of } \\
V(\$ \text { Million })\end{array}$ & $\begin{array}{l}\text { No. of } \\
\text { Firms }\end{array}$ & $\begin{array}{c}\text { Average } \tilde{\gamma} \\
(\%)\end{array}$ & $\begin{array}{l}\text { Average } \tilde{\gamma} \\
\text { (\$ Million) }\end{array}$ & $\begin{array}{c}\text { Range of } \\
V(\$ \text { Million })\end{array}$ & $\begin{array}{l}\text { No. of } \\
\text { Firms }\end{array}$ & $\begin{array}{c}\text { Average } \tilde{\gamma} \\
(\%)\end{array}$ & $\begin{array}{l}\text { Average } \widetilde{\gamma} \\
\text { (\$ Million) }\end{array}$ \\
\hline $0<V \leq 10$ & $\begin{array}{l}309 \\
(25.2)\end{array}$ & $\begin{array}{l}4.05 \\
(5.40 ; 61.2)\end{array}$ & $\begin{array}{l}0.20 \\
(3.20 ; 50.9)\end{array}$ & $0<V \leq 100$ & $\begin{array}{l}61 \\
(17.9)\end{array}$ & $\begin{array}{l}2.12 \\
(1.89 ; 59.0)\end{array}$ & $\begin{array}{l}1.69 \\
(1.67 ; 65.0)\end{array}$ \\
\hline $10<V \leq 20$ & $\begin{array}{l}184 \\
(15.0)\end{array}$ & $\begin{array}{l}2.02 \\
(3.11 ; 55.0)\end{array}$ & $\begin{array}{l}0.23 \\
(2.01 ; 52.2)\end{array}$ & $100<V \leq 200$ & $\begin{array}{l}62 \\
(18.1)\end{array}$ & $\begin{array}{l}-1.32 \\
(-0.76 ; 45.2)\end{array}$ & $\begin{array}{c}1.56 \\
(-0.79 ; 54.8)\end{array}$ \\
\hline $20<v \leq 30$ & $\begin{array}{l}118 \\
(9.6)\end{array}$ & $\begin{array}{l}1.54 \\
(1.89 ; 53.4)\end{array}$ & $\begin{array}{l}0.13 \\
(2.44 ; 51.3)\end{array}$ & $200<v \leq 300$ & $\begin{array}{c}42 \\
(12.3)\end{array}$ & $\begin{array}{l}2.66 \\
(1.65 ; 50.0)\end{array}$ & $\begin{array}{l}6.30 \\
(2.67 ; 52.2)\end{array}$ \\
\hline $30<V \leq 40$ & $\begin{array}{l}73 \\
(5.9)\end{array}$ & $\begin{array}{l}-1.60 \\
(-1.69 ; 41.1)\end{array}$ & $\begin{array}{l}-0.46 \\
(-0.11 ; 46.6)\end{array}$ & $300<V \leq 400$ & $\begin{array}{l}30 \\
(0.88)\end{array}$ & $\begin{array}{c}0.84 \\
(-0.36 ; 53.3)\end{array}$ & $\begin{array}{c}13.68 \\
(-0.41 ; 60.0)\end{array}$ \\
\hline $40<V \leq 50$ & $\begin{array}{l}64 \\
(5.2)\end{array}$ & $\begin{array}{l}0.81 \\
(1.00 ; 54.7)\end{array}$ & $\begin{array}{l}0.41 \\
(2.07 ; 51.6)\end{array}$ & $400<V \leq 500$ & $\begin{array}{l}16 \\
(4.7)\end{array}$ & $\begin{array}{l}1.78 \\
(1.12 ; 62.5)\end{array}$ & $\begin{array}{l}8.61 \\
(0.91 ; 75.0)\end{array}$ \\
\hline $50<v \leq 60$ & $\begin{array}{l}41 \\
\text { (3.3) }\end{array}$ & $\begin{array}{l}2.40 \\
(1.29 ; 58.5)\end{array}$ & $\begin{array}{l}1.19 \\
(5.27 ; 65.8)\end{array}$ & $500<v \leq 600$ & $\begin{array}{l}14 \\
(4.1)\end{array}$ & $\begin{array}{l}1.41 \\
(0.78 ; 64.3)\end{array}$ & $\begin{array}{l}11.73 \\
(0.74 ; 71.4)\end{array}$ \\
\hline $60<V \leq 70$ & $\begin{array}{l}47 \\
(3.8)\end{array}$ & $\begin{array}{l}2.57 \\
(2.18 ; 66.0)\end{array}$ & $\begin{array}{l}1.75 \\
(4.54 ; 59.6)\end{array}$ & $600<V \leq 700$ & $\begin{array}{l}21 \\
(6.2)\end{array}$ & $\begin{array}{l}2.09 \\
(1.39 ; 62.0)\end{array}$ & $\begin{array}{l}13.36 \\
(1.08 ; 66.7)\end{array}$ \\
\hline $70<v \leq 80$ & $\begin{array}{l}28 \\
(2.3)\end{array}$ & $\begin{array}{l}1.72 \\
(0.82 ; 50.0)\end{array}$ & $\begin{array}{l}-0.02 \\
(1.59 ; 39.3)\end{array}$ & $700<V \leq 800$ & $\begin{array}{l}15 \\
(4.4)\end{array}$ & $\begin{array}{l}1.00 \\
(0.55 ; 73.3)\end{array}$ & $\begin{array}{l}8.56 \\
(0.72 ; 73.3)\end{array}$ \\
\hline $80<V \leq 90$ & $\begin{array}{l}23 \\
(1.9)\end{array}$ & $\begin{array}{l}0.00 \\
(0.96 ; 56.5)\end{array}$ & $\begin{array}{l}0.22 \\
(0.44 ; 65.2)\end{array}$ & $800<V \leq 900$ & $\begin{array}{l}10 \\
(2.9)\end{array}$ & $\begin{array}{l}-0.38 \\
(0.19 ; 50.0)\end{array}$ & $\begin{array}{l}-6.823 \\
(0.32 ; 50.0)\end{array}$ \\
\hline $90<V \leq 100$ & $\begin{array}{l}19 \\
(1.5)\end{array}$ & $\begin{array}{l}2.63 \\
(1.57 ; 58.0)\end{array}$ & $\begin{array}{l}1.55 \\
(1.42 ; 52.6)\end{array}$ & $900<V \leq 1000$ & $\begin{array}{l}9 \\
(2.6)\end{array}$ & $\begin{array}{l}-0.88 \\
(-0.55 ; 33.3)\end{array}$ & $\begin{array}{l}-13.30 \\
(-0.77 ; 22.2)\end{array}$ \\
\hline $100<V$ & $\begin{array}{l}321 \\
(26.1)\end{array}$ & $\begin{array}{l}0.44 \\
(0.60 ; 51.6)\end{array}$ & $\begin{array}{l}35.76 \\
(2.39 ; 51.4)\end{array}$ & $1000<V$ & $\begin{array}{l}61 \\
(17.9)\end{array}$ & $\begin{array}{l}0.49 \\
(0.77 ; 60.7)\end{array}$ & $\begin{array}{l}-24.16 \\
(-0.02 ; 57.4)\end{array}$ \\
\hline
\end{tabular}

${ }^{a}$ Abnormal dollar returns are obtained by estimating $\gamma_{j}$ after pre-multiplying the terms $\left(r_{j t}-r_{f t}\right)$ and $\left(r_{m t}-r_{f t}\right)$ with $V$, the prior end-of-period market value of total equity. To be included, a firm must have a minimum of 24 valid returns over the 48-month period -60 through $-13 . Z=(1 / \sqrt{N}) \sum_{j} \widehat{\gamma}_{j} / \widehat{\sigma}_{\gamma_{j}} \stackrel{\text { as }}{\sim} N(0,1)$, where $N$ is the sample size and $\widehat{\sigma}_{\gamma_{j}}$ is the estimated standard error of $\gamma_{j}$.

$\mathrm{b}$ In this column, the number of firms in percent of the total sample is given in parentheses.

The results in Table 8 for TSE-listed bidders show a tendency for bidder abnormal returns to decrease with increasing bidder size. For the 309 smallest bidders, with total equity values less than $\$ 10$ million, the average abnormal return is $4.05 \%$ with a highly significant $Z$-value of 5.40 . For bidder equity valuesexceeding $\$ 40$ million (543 cases or $44 \%$ of the sample), the average abnormal returns are largely insignificant (with the exception of $60<V \leq 70$ ). Notice also that, when bidder gains are measured in terms of dollar values, seven of the 11 size groups (including the largest, where $V>\$ 100$ million) indicate statistically significant bidder gains, with no clear relationship to bidder size. These results support the argument that estimates of a given dollar gain to bidder firms, particularly when measured as a percentage of equity, suffer an attenuation bias that increases with bidder equity size. 
Turning to the NYSE-listed bidders in Table 8, there is little evidence of significant bidder gains regardless of the size group and whether one measures gains in percentage or dollar terms. There is slight evidence of positive gains in the very smallest size group ( $V<\$ 100$ million), with an average $\widehat{\gamma}$ of $2.12 \%$ ( $Z$-value 1.89 ) or $\$ 1.69$ million ( $Z$-value 1.67 ). These results are as expected since even the smallest NYSE-listed bidders are large compared to the TSE-listed bidders, thus creating potentially serious measurement problems across all size groups.

\section{B. Partial Anticipation of Acquisition Activity}

Since the market reacts to the unanticipated portion of the information in the acquisition announcement, partial anticipation of acquisition activity attenuates the announcement effect. A number of approaches have been implemented that address this problem. For example, Schipper and Thompson (1983) focus on the announcement of entire acquisition programs. This announcement is arguably at the beginning of the process that leads the market to partially anticipate future takeover activity. Asquith, Bruner, and Mullins (1983), Loderer and Martin (1990), and Song and Walkling (1998) focus in particular on initial acquisition announcements following a "dormant" period. Such announcements are also a priori less predictable. A third approach is to explicitly model the acquisition probability, as in Malatesta and Thompson (1985), (1986) and Eckbo, Maksimovic, and Williams (1990). Below, we exploit the Malatesta-Thompson (henceforth, MT) framework to shed light on the degree to which our sample acquisitions were partially anticipated.

Before invoking the MT framework, note in Table 9 the actual frequency distribution of the total number of acquisitions $\left(N_{j}\right)$ performed by our TSE-listed and NYSE-listed bidders over the 20-year sample period. For domestic bidders, total acquisition activity is given by the total number of targets listed in the Merger Register for each bidder firm over the sample period (columns two and five). For NYSE-listed bidders, $N_{j}$ is given by the number of targets announced in the Wall Street Journal. The average number of acquisitions per bidder is six for TSElisted bidders and nine for NYSE-listed bidders. Table 9 partitions $N_{j}$ into 10 subgroups, ranging from one to 25 (the sample maximum). The percentage of the bidders that falls into each of the 10 groups is surprisingly similar across TSElisted and NYSE-listed bidders. If the market's estimate of acquisition frequency reflects the distribution of $N_{j}$ in Table 9, then it is difficult to argue that the degree of partial anticipation is significantly greater in the U.S. than in the domestic sample.

The MT model implies that the event parameter $\gamma_{j}$ estimated from equation (3) provides an unbiased estimate of bidder $j$ 's total acquisition gain $\left(v_{j}\right)$ even if the market assigns a positive probability $q_{j}$ that an acquisition will be announced in each period. Specifically, the announcement effect of an acquisition is given by $\left(1-q_{j}\right) v_{j}$, while the market reduces the bidder's stock price by $-q_{j} v_{j}$ in the 
"no acquisition" event. Market efficiency implies that the unconditional expected abnormal return across the two mutually exclusive events equals zero, i.e.,

$$
\begin{aligned}
& {\left[\left(1-q_{j}\right) v_{j} \mid d_{j}=1\right]+\left[-q_{j} v_{j} \mid d_{j}=0\right]=} \\
& \quad-q_{j} v_{j}+\left(v_{j} \mid d_{j}=1\right)=\alpha_{j}+\gamma_{j} d_{j}=0
\end{aligned}
$$

\section{TABLE 9}

\section{Average Monthly Abnormal Returns to Domestic and Foreign (U.S.) Bidders Classified by} the Bidder's Acquisition Frequency during the Sample Period (1964-1983)

OLS estimates of the constant term $\alpha$ and the abnormal return coefficient $\gamma$ in the excess return market model,

$$
r_{j t}-r_{f t}=\alpha_{j}+\beta_{j}\left(r_{m t}-r_{f t}\right)+\gamma_{j} d_{j t}+\epsilon_{j t},
$$

where $r_{j t}, r_{f t}$, and $r_{m t}$ are the continuously compounded rates of return to security $j$, the risk-free asset, and the value-weighted market index over period $t$; $d_{j t}$ takes on a value of one in the event period and zero otherwise; and $\epsilon_{j t}$ is a zero mean disturbance term. The estimation period is month +13 through month +60 , i.e., excluding months +1 through +12 . For the bidder firms listed on the TSE, the total acquisition activity is given by the number of targets in the sample, based on the information in the Canadian Merger Register. For the bidder firms listed in the NYSE, the total acquisition activity is given by the number of

\begin{tabular}{|c|c|c|c|c|c|c|}
\hline \multirow{2}{*}{$\begin{array}{c}\text { Total Number of } \\
\text { Acquisitions }\left(N_{j}\right) \\
\text { per Bidder Firm } \\
\text { during the 1964-1983 } \\
\text { Period } \\
\end{array}$} & \multicolumn{3}{|c|}{ 1,227 Bidder Firms Listed on the TSE } & \multicolumn{3}{|c|}{328 Bidder Firms Listed on the NYSE } \\
\hline & $\begin{array}{l}\text { No. of } \\
\text { Firms } \\
\end{array}$ & $\begin{array}{c}\text { Average } \widetilde{\alpha} \\
(\%)\end{array}$ & $\begin{array}{c}\begin{array}{c}\text { Average } \tilde{\gamma} \\
(\%)\end{array} \\
\end{array}$ & $\begin{array}{r}\text { Number of } \\
\text { Firms } \\
\end{array}$ & $\begin{array}{c}\text { Average } \widetilde{\alpha} \\
(\%)\end{array}$ & $\begin{array}{c}\text { Average } \widetilde{\gamma} \\
(\%)\end{array}$ \\
\hline $1 \leq N_{j} \leq 2$ & $\begin{array}{l}272 \\
(22.2)\end{array}$ & $\begin{array}{l}-2.45 \\
(-4.36 ; 41.5)\end{array}$ & $\begin{array}{l}0.95 \\
(0.72 ; 50.4)\end{array}$ & $\begin{array}{l}32 \\
(9.8)\end{array}$ & $\begin{array}{l}-2.29 \\
(-6.18 ; 28.1)\end{array}$ & $\begin{array}{l}1.58 \\
(1.13 ; 59.4)\end{array}$ \\
\hline $3 \leq N_{j} \leq 5$ & $\begin{array}{l}200 \\
(16.3)\end{array}$ & $\begin{array}{l}-0.16 \\
(-0.65 ; 49.3)\end{array}$ & $\begin{array}{l}2.85 \\
(5.31 ; 59.0)\end{array}$ & $\begin{array}{l}59 \\
(18.0)\end{array}$ & $\begin{array}{l}-1.96 \\
(-7.89 ; 32.2)\end{array}$ & $\begin{array}{l}-0.36 \\
(-0.52 ; 47.5)\end{array}$ \\
\hline $6 \leq N_{j} \leq 7$ & $\begin{array}{l}165 \\
(13.4)\end{array}$ & $\begin{array}{l}2.23 \\
(3.37 ; 60.0)\end{array}$ & $\begin{array}{l}2.47 \\
(2.75 ; 55.2)\end{array}$ & $\begin{array}{c}45 \\
(13.7)\end{array}$ & $\begin{array}{l}-1.41 \\
(-4.37 ; 37.8)\end{array}$ & $\begin{array}{l}-0.24 \\
(0.04 ; 40.0)\end{array}$ \\
\hline $8 \leq N_{j} \leq 10$ & $\begin{array}{l}160 \\
(13.0)\end{array}$ & $\begin{array}{l}-2.73 \\
(-3.27 ; 45.0)\end{array}$ & $\begin{array}{l}1.00 \\
(1.51 ; 55.6)\end{array}$ & $\begin{array}{l}77 \\
(23.5)\end{array}$ & $\begin{array}{l}-1.91 \\
(-7.54 ; 29.9)\end{array}$ & $\begin{array}{l}1.34 \\
(1.49 ; 61.0)\end{array}$ \\
\hline $11 \leq N_{j} \leq 12$ & $\begin{array}{l}77 \\
(6.3)\end{array}$ & $\begin{array}{l}-1.15 \\
(-0.07 ; 48.1)\end{array}$ & $\begin{array}{l}2.23 \\
(2.70 ; 58.4)\end{array}$ & $\begin{array}{c}38 \\
(11.6)\end{array}$ & $\begin{array}{l}-1.41 \\
(-4.36 ; 31.6)\end{array}$ & $\begin{array}{l}0.10 \\
(0.13 ; 50.0)\end{array}$ \\
\hline $13 \leq N_{j} \leq 15$ & $\begin{array}{l}41 \\
(3.3)\end{array}$ & $\begin{array}{c}0.01 \\
(-0.19 ; 46.3)\end{array}$ & $\begin{array}{l}-0.49 \\
(-0.86 ; 53.7)\end{array}$ & $\begin{array}{c}34 \\
(10.3)\end{array}$ & $\begin{array}{l}-0.28 \\
(0.04 ; 58.8)\end{array}$ & $\begin{array}{l}2.55 \\
(1.86 ; 61.8)\end{array}$ \\
\hline $16 \leq N_{j} \leq 17$ & $\begin{array}{l}49 \\
(4.0)\end{array}$ & $\begin{array}{l}1.46 \\
(2.37 ; 71.4)\end{array}$ & $\begin{array}{l}2.36 \\
(1.79 ; 57.1)\end{array}$ & $\begin{array}{l}15 \\
(4.6)\end{array}$ & $\begin{array}{l}0.21 \\
(1.04 ; 53.3)\end{array}$ & $\begin{array}{l}0.69 \\
(0.09 ; 60.0)\end{array}$ \\
\hline $18 \leq N_{j} \leq 20$ & $\begin{array}{l}18 \\
(1.5)\end{array}$ & $\begin{array}{l}10.63 \\
(6.54 ; 77.8)\end{array}$ & $\begin{array}{l}-2.47 \\
(-1.42 ; 38.9)\end{array}$ & $\begin{array}{l}17 \\
(5.2)\end{array}$ & $\begin{array}{l}-1.36 \\
(-2.82 ; 29.4)\end{array}$ & $\begin{array}{l}0.65 \\
(0.03 ; 52.9)\end{array}$ \\
\hline $21 \leq N_{j} \leq 22$ & $\begin{array}{l}20 \\
(1.6)\end{array}$ & $\begin{array}{l}6.53 \\
(4.81 ; 85.0)\end{array}$ & $\begin{array}{l}0.48 \\
(0.45 ; 45.0)\end{array}$ & $\begin{array}{l}3 \\
(0.9)\end{array}$ & $\begin{array}{l}1.76 \\
(1.62 ; 66.7)\end{array}$ & $\begin{array}{l}-3.46 \\
(-0.64 ; 33.3)\end{array}$ \\
\hline $23 \leq N_{j} \leq 25$ & $\begin{array}{l}25 \\
(2.0)\end{array}$ & $\begin{array}{l}-2.75 \\
(-2.12 ; 32.0)\end{array}$ & $\begin{array}{l}0.58 \\
(0.46 ; 52.0)\end{array}$ & $\begin{array}{l}8 \\
(2.4)\end{array}$ & $\begin{array}{l}-1.49 \\
(-1.58 ; 25.0)\end{array}$ & $\begin{array}{l}2.00 \\
(0.87 ; 62.5)\end{array}$ \\
\hline
\end{tabular}
targets announced in the Wall Street Journal over the sample period.

( $Z$-value and percent positive in parentheses) $^{\mathrm{a}}$

\footnotetext{
a To be included, a firm must have a minimum of 24 valid returns over the 48-month period -60 through -13. $Z=(1 / \sqrt{N}) \sum_{j} \widehat{\gamma}_{j} / \widehat{\sigma}_{\gamma_{j}} \stackrel{\text { as }}{\sim} N(0,1)$, where $N$ is the sample size and $\widehat{\sigma}_{\gamma_{j}}$ is the estimated standard error of $\gamma_{j}$.

${ }^{b}$ The number of firms in percent of the total sample is in parentheses.
} 
where, as in equation (3), $d_{j}$ is a zero-one conditioning variable for the event of an acquisition announcement. MT further assume that expected returns are generated by a one-factor model such as the CAPM, i.e.,

$$
E\left(r_{j t}\right)-r_{f t}=\beta_{j}\left[E\left(r_{m t}\right)-r_{f t}\right]
$$

Adding (8) to the right-hand side of (9) yields our original conditional market model (3) with $\alpha_{j}=-q v$ and $\gamma_{j}=v$.

Our earlier conclusion that TSE bidders, on average, outperform NYSE bidders holds a fortiori under the MT framework since $\gamma_{j}$ is unbiased for $v_{j}$ even if $q_{j}>0$. Furthermore, it is interesting to compare the average values of $\alpha_{j}$ across the two categories of bidders to infer in which sample the market assigns the greatest prior probability of an acquisition event. As Table 9 shows, for NYSElisted bidders, seven of the 10 estimated values of the average $\alpha_{j}$ are negative and significant at the $1 \%$ level. The average value of $\alpha_{j}$ for TSE-listed bidders is typically larger in absolute value and six of 10 are significant at the $1 \%$ level.

The variation in the average estimate of $\gamma_{j}$ across domestic and foreign bidders raises the question of whether differences in $\alpha_{j}$ reflect systematic differences in $v_{j}$ or in $q_{j}$ (or both). To address this question, we isolate the value of $q$ and test the following hypothesis,

$$
\mathrm{H}_{0}: \frac{\alpha}{\gamma}=\frac{-\mathrm{qv}}{\mathrm{v}}=-q=0 .
$$

For the purpose of this test, we form the sample average $(1 / N) \sum_{j}\left(\alpha_{j} / \gamma_{j}\right)$, which (under the central limit theorem) is distributed asymptotically normal. Estimating the variance of $\alpha / \gamma$ cross-sectionally, a standard $t$-test rejects $\mathrm{H}_{0}$ at the $1 \%$ level for each of the two bidder groups. However, we cannot reject the hypothesis that the value of $q$ implied by $\alpha / \gamma$ is the same for domestic and foreign bidders. These conclusions hold whether measuring abnormal returns in percentage terms or in terms of dollar values. In sum, it appears that the market assigns a non-zero prior acquisition probability that is similar across our TSE-listed and NYSE-listed bidder firms.

\section{Conclusions}

The literature on corporate acquisitions indicates that gains to bidder firms in the U.S. are largely insignificant. While the evidence is consistent with the hypothesis that competition among bidder firms drives the rents from acquisition activity to the target shareholders, it is also widely recognized that measured bidder abnormal returns may contain an attenuation bias. The bias may arise when the bidder is large relative to the target (and, therefore, also relative to the dollar gain in the transaction) or when the market anticipates takeovers based on the bidder's record as a frequent acquiror. As a result, it is difficult to assess the true performance of U.S. bidders.

This paper addresses the controversy over the true gains to bidder firms by studying a large sample of domestic and foreign acquisitions in Canada. The foreign bidders are all U.S. firms listed on the NYSE. We find robust evidence that 
domestic bidders realize significantly positive announcement month (and two-day announcement period) abnormal stock returns. At the same time, U.S. bidders in Canada earn statistically insignificant abnormal returns. This evidence is also corroborated by abnormal annual earnings data.

The paper performs several investigations into the possible source of the differential performance of the two categories of bidder firms. First, we test and reject the hypothesis that foreign direct investment controls in place during the second half of our sample period has reduced average gains to the NYSE-listed foreign bidders in our sample. Second, TSE-listed bidders that outperform their U.S. counterparts tend to undertake conglomerate rather than horizontal acquisitions. Thus, a relative product market disadvantage to foreign bidders does not appear to explain the superior domestic bidder performance. Third, we show that the market tends to react positively to domestic bids where the payment is in the form of bidder shares. This is in contrast to extant evidence for U.S. domestic acquisitions where all-stock offers, on average, are associated with a non-positive or even negative market reaction. The negative market reaction is consistent with adverse selection effects in U.S. issue markets, and our analysis raises the question of whether the greater announcement returns to domestic all-cash offers is the result of lower adverse selection effects of Canadian targeted domestic equity issues.

Finally, we show that the most profitable domestic acquisitions are the ones where the bidder and targets have similar total equity sizes. The U.S. bidders in our sample are, on average, eight times the size of their Canadian counterparts, which suggests that the insignificant U.S. bidder performance, in part, reflects a measurement problem. We also document similar acquisition frequencies across domestic and U.S. bidders, and we fail to reject structural tests of the hypothesis that the market assigns similar prior acquisition probabilities to the NYSE-listed and the TSE-listed bidder in our sample.

\section{References}

Asquith, P.; R. F. Bruner; and D. W. Mullins, Jr. "The Gains to Bidding Firms from Merger." Journal of Financial Economics, 11 (1983), 121-139.

Betton, S., and B. E. Eckbo. "Toeholds, Bid-Jumps, and Expected Payoffs in Takeovers." Review of Financial Studies (forthcoming 2000).

Carleton, W. T.; A. K. Guilkey; R. S. Harris; and J. F. Stewart. "An Empirical Analysis of the Role of the Medium of Exchange in Mergers.” Journal of Finance, 38 (1983), 813-826.

Clarkson, S. Canada and the Reagan Challenge. Toronto: James Lorimer \& Co. (1982).

Eckbo, B. E. "Mergers and the Market for Corporate Control: The Canadian Evidence." Canadian Journal of Economics, 19 (1986), 236-260.

(1992), 1005-1029.

"Mergers and the Value of Antitrust Deterrence." Journal of Finance, 47

Eckbo, B. E.; R. M. Giammarino; and R. L. Heinkel. "Asymmetric Information and the Medium of Exchange in Takeovers." Review of Financial Studies, 3 (1990), 651-676.

Eckbo, B. E., and H. Langohr. "Information Disclosure, Method of Payment, and Takeover Premiums: Public and Private Tender Offers in France." Journal of Financial Economics, 24 (1989), 363-403.

Eckbo, B. E.; V. Maksimovic; and J. Williams. "Consistent Estimation of Cross-Sectional Models in Event Studies." Review of Financial Studies, 3 (1990), 343-365.

Eckbo, B. E., and R. W. Masulis. "Seasoned Public Offerings: A Survey." In Finance, Series of Handbooks in Operations Research and Management Science, vol. 9, R. A. Jarrow, V. Maksimovic, and W. T. Ziemba, eds. Holland: North-Holland (1995), 1017-1072. 
Eckbo, B. E., and S. Verma. "Voting Power and Valuation Effects of Security Offerings." Working Paper, Dartmouth College (1992).

Fishman, M. J. "Preemptive Bidding and the Role of the Medium of Exchange." Journal of Finance, 44 (1989), 41-58.

Franks, J. R.; R. S. Harris; and C. Mayer. "Means of Payment in Takeovers: Results for the U.K. and the U.S." In Corporate Takeovers: Causes and Consequences, A. Auerback, ed. NBER, Chicago, IL: Univ. of Chicago Press (1988).

Gilson, R. J.; M. S. Scholes; and M. A. Wolfson. "Taxation and the Dynamics of Corporate Control: The Uncertain Case for Tax-Motivated Acquisitions." In Knights, Raiders and Targets: The Impact of the Hostile Takeover, J. C. Coffee, Jr.; L. Lowenstein; and S. Rose-Ackerman, eds. New York, NY: Oxford Univ. Press (1988).

Gray, H. Foreign Direct Investment in Canada. Government of Canada (1972).

Hansen, R. "A Theory for the Choice of Exchange Medium in Mergers and Acquisitions." Journal of Business, 60 (1987), 75-95.

Hirshleifer, D. "Mergers and Acquisitions: Strategic and Informational Issues." In Finance, Handbooks in Operations Research and Management Science, vol. 9, R. A. Jarrow, V. Maksimovic, and W. T. Ziemba, eds. Holland: North-Holland (1995), 839-885.

Huang, R., and R. Walkling. "Target Abnormal Returns Associated with Acquisition Announcements: Payment, Acquisition Form and Managerial Resistance. Journal of Financial Economics, 19 (1987), 329-350.

Jarrell, G. A., and M. Bradley. "The Economic Effects of Federal and State Regulations of Cash Tender Offers." Journal of Law and Economics, (1980), 371-407.

Jarrell, G. A.; J. A. Brickley; and J. M. Netter. "The Market for Corporate Control: The Empirical Evidence Since 1980.” Journal of Economic Perspectives, 2 (1988), 49-68.

Jarrell, G. A., and A. B. Poulsen. "The Returns to Acquiring Firms in Tender Offers: Evidence from Three Decades." Financial Management, 18 (1989), 12-19.

Jensen, M. C., and R. S. Ruback. "The Market for Corporate Control: The Scientific Evidence." Journal of Financial Economics, 11 (1983), 5-50.

Loderer, C., and K. Martin. "Corporate Acquisitions by Listed Firms: The Experience of a Comprehensive Sample." Financial Management, 19 (1990), 17-33.

Malatesta, P. H., and R. Thompson. "Partially Anticipated Events: A Model of Stock Price Reactions with an Application to Corporate Acquisitions." Journal of Financial Economics, 14 (1985), 237250.

"Stock Price Reactions to Partially Anticipated Events: Evidence on the Economic Impact of Corporate Acquisition Attempts." Research in Finance, 6 (1986), 119-148.

Myers, S. C., and N. S. Majluf. "Corporate Financing and Investment Decisions when Firms Have Information Investors Do Not Have." Journal of Financial Economics, 13 (1984), 197-221.

Ravenscraft, D., and F. M. Scherer. "Life after Takeover.” Journal of Industrial Economics, 36 (1987), 147-157. tion, 7 (1989), 101-117.

"The Profitability of Mergers." International Journal of Industrial Organiza-

Roll, R. "The Hubris Hypothesis of Corporate Takeovers.” Journal of Business, 59 (1986), 197-216.

Schipper, K., and R. Thompson. "Evidence on the Capitalized Value of Merger Activity for Acquiring Firms." Journal of Financial Economics, 11 (1983), 85-119.

Schwert, G. W. "Markup Pricing in Mergers and Acquisitions." Journal of Financial Economics, 41 (1996), 153-192.

Song, M. H., and R. A. Walkling "Abnormal Returns to Rivals of Acquisition Targets: A Test of the Acquisition Probability Hypothesis," Working Paper, Ohio State Univ. (1998).

Theil, H. Principles of Econometrics. New York, NY: John Wiley (1971).

Travlos, N. "Corporate Takeover Bids, Method of Payment and Bidding Firms' Stock Returns." Journal of Finance, 45 (1987), 943-964. 
http://www.jstor.org

\title{
LINKED CITATIONS
}

- Page 1 of 5 -

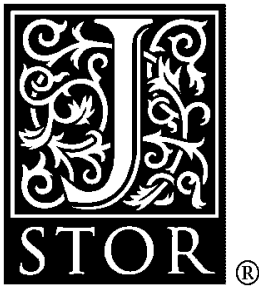

You have printed the following article:

Gains to Bidder Firms Revisited: Domestic and Foreign Acquisitions in Canada

B. Espen Eckbo; Karin S. Thorburn

The Journal of Financial and Quantitative Analysis, Vol. 35, No. 1. (Mar., 2000), pp. 1-25.

Stable URL:

http://links.jstor.org/sici?sici=0022-1090\%28200003\%2935\%3A1\%3C1\%3AGTBFRD\%3E2.0.CO\%3B2-Z

This article references the following linked citations. If you are trying to access articles from an off-campus location, you may be required to first logon via your library web site to access JSTOR. Please visit your library's website or contact a librarian to learn about options for remote access to JSTOR.

\section{[Footnotes]}

\author{
${ }^{1}$ The Hubris Hypothesis of Corporate Takeovers \\ Richard Roll \\ The Journal of Business, Vol. 59, No. 2, Part 1. (Apr., 1986), pp. 197-216. \\ Stable URL: \\ http://links.jstor.org/sici?sici=0021-9398\%28198604\%2959\%3A2\%3C197\%3ATHHOCT\%3E2.0.CO\%3B2-8
}

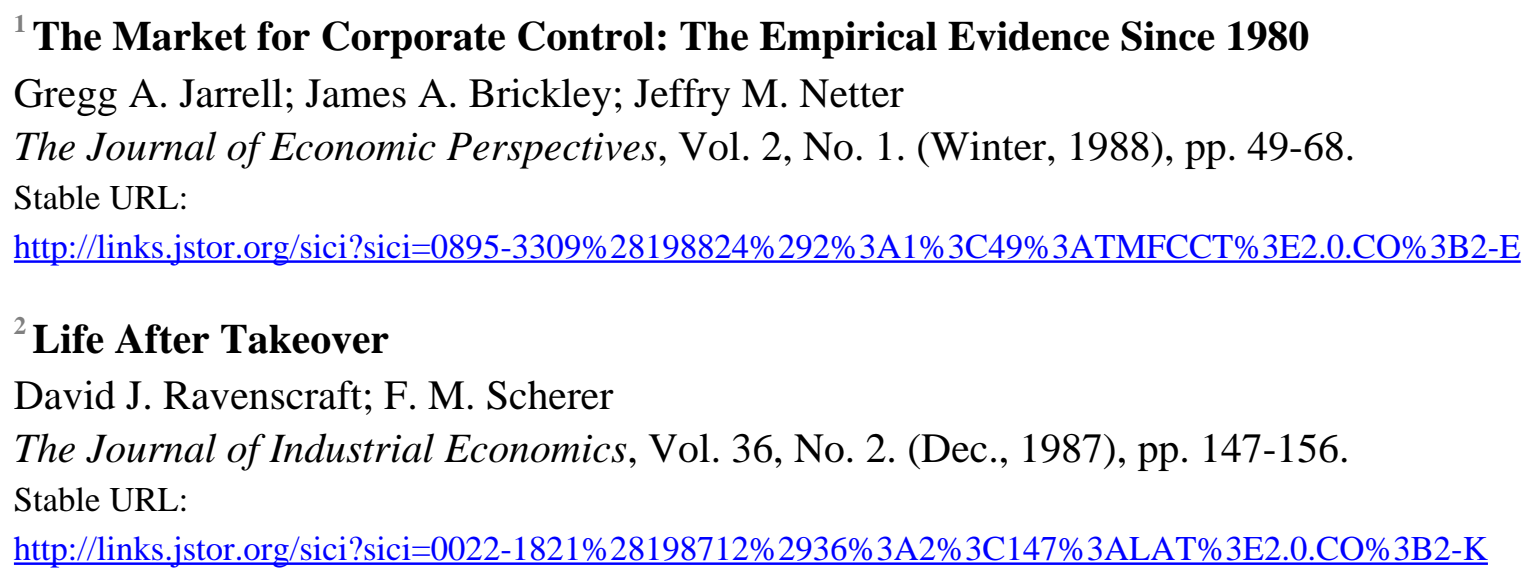

\footnotetext{
${ }^{4}$ The Economic Effects of Federal and State Regulations of Cash Tender Offers Gregg A. Jarrell; Michael Bradley

Journal of Law and Economics, Vol. 23, No. 2. (Oct., 1980), pp. 371-407.

Stable URL:

http://links.jstor.org/sici?sici=0022-2186\%28198010\%2923\%3A2\%3C371\%3ATEEOFA\%3E2.0.CO\%3B2-5
}

NOTE: The reference numbering from the original has been maintained in this citation list. 
http://www.jstor.org

\section{LINKED CITATIONS}

- Page 2 of 5 -

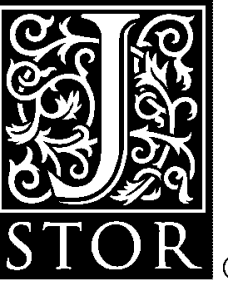

\footnotetext{
${ }^{10}$ Mergers and the Value of Antitrust Deterrence

B. Espen Eckbo
}

The Journal of Finance, Vol. 47, No. 3, Papers and Proceedings of the Fifty-Second Annual Meeting of the American Finance Association, New Orleans, Louisiana January 3-5, 1992. (Jul., 1992), pp. 1005-1029.

Stable URL:

http://links.jstor.org/sici?sici=0022-1082\%28199207\%2947\%3A3\%3C1005\%3AMATVOA\%3E2.0.CO\%3B2-J

\section{${ }^{11}$ An Empirical Analysis of the Role of the Medium of Exchange in Mergers}

Willard T. Carleton; David K. Guilkey; Robert S. Harris; John F. Stewart

The Journal of Finance, Vol. 38, No. 3. (Jun., 1983), pp. 813-826.

Stable URL:

http://links.jstor.org/sici?sici=0022-1082\%28198306\%2938\%3A3\%3C813\%3AAEAOTR\%3E2.0.CO\%3B2-L

\section{${ }^{12}$ A Theory for the Choice of Exchange Medium in Mergers and Acquisitions}

Robert G. Hansen

The Journal of Business, Vol. 60, No. 1. (Jan., 1987), pp. 75-95.

Stable URL:

http://links.jstor.org/sici?sici=0021-9398\%28198701\%2960\%3A1\%3C75\%3AATFTCO\%3E2.0.CO\%3B2-E

\section{${ }^{12}$ Preemptive Bidding and the Role of the Medium of Exchange in Acquisitions}

Michael J. Fishman

The Journal of Finance, Vol. 44, No. 1. (Mar., 1989), pp. 41-57.

Stable URL:

http://links.jstor.org/sici?sici=0022-1082\%28198903\%2944\%3A1\%3C41\%3APBATRO\%3E2.0.CO\%3B2-3

${ }^{12}$ Asymmetric Information and the Medium of Exchange in Takeovers: Theory and Tests

B. Espen Eckbo; Ronald M. Giammarino; Robert L. Heinkel

The Review of Financial Studies, Vol. 3, No. 4. (1990), pp. 651-675.

Stable URL:

http://links.jstor.org/sici?sici=0893-9454\%281990\%293\%3A4\%3C651\%3AAIATMO\%3E2.0.CO\%3B2-2

\footnotetext{
${ }^{13}$ Asymmetric Information and the Medium of Exchange in Takeovers: Theory and Tests B. Espen Eckbo; Ronald M. Giammarino; Robert L. Heinkel

The Review of Financial Studies, Vol. 3, No. 4. (1990), pp. 651-675.

Stable URL:

http://links.jstor.org/sici?sici=0893-9454\%281990\%293\%3A4\%3C651\%3AAIATMO\%3E2.0.CO\%3B2-2
}

NOTE: The reference numbering from the original has been maintained in this citation list. 
http://www.jstor.org

\section{LINKED CITATIONS}

- Page 3 of 5 -

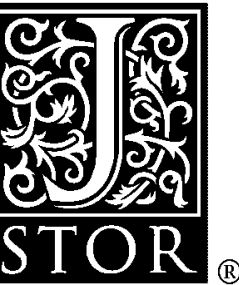

\section{References}

\section{Toeholds, Bid Jumps, and Expected Payoffs in Takeovers}

Sandra Betton; B. Espen Eckbo

The Review of Financial Studies, Vol. 13, No. 4. (Winter, 2000), pp. 841-882.

Stable URL:

http://links.jstor.org/sici?sici=0893-9454\%28200024\%2913\%3A4\%3C841\%3ATBJAEP\%3E2.0.CO\%3B2-N

\section{An Empirical Analysis of the Role of the Medium of Exchange in Mergers}

Willard T. Carleton; David K. Guilkey; Robert S. Harris; John F. Stewart

The Journal of Finance, Vol. 38, No. 3. (Jun., 1983), pp. 813-826.

Stable URL:

http://links.jstor.org/sici?sici=0022-1082\%28198306\%2938\%3A3\%3C813\%3AAEAOTR\%3E2.0.CO\%3B2-L

\section{Mergers and the Market for Corporate Control: The Canadian Evidence}

B. Espen Eckbo

The Canadian Journal of Economics / Revue canadienne d'Economique, Vol. 19, No. 2. (May, 1986), pp. 236-260.

Stable URL:

http://links.jstor.org/sici?sici=0008-4085\%28198605\%2919\%3A2\%3C236\%3AMATMFC\%3E2.0.CO\%3B2-\%23

\section{Mergers and the Value of Antitrust Deterrence}

B. Espen Eckbo

The Journal of Finance, Vol. 47, No. 3, Papers and Proceedings of the Fifty-Second Annual Meeting of the American Finance Association, New Orleans, Louisiana January 3-5, 1992. (Jul., 1992), pp. 1005-1029.

Stable URL:

http://links.jstor.org/sici?sici=0022-1082\%28199207\%2947\%3A3\%3C1005\%3AMATVOA\%3E2.0.CO\%3B2-J

Asymmetric Information and the Medium of Exchange in Takeovers: Theory and Tests

B. Espen Eckbo; Ronald M. Giammarino; Robert L. Heinkel

The Review of Financial Studies, Vol. 3, No. 4. (1990), pp. 651-675.

Stable URL:

http://links.jstor.org/sici?sici=0893-9454\%281990\%293\%3A4\%3C651\%3AAIATMO\%3E2.0.CO\%3B2-2

NOTE: The reference numbering from the original has been maintained in this citation list. 
http://www.jstor.org

\section{LINKED CITATIONS}

- Page 4 of 5 -

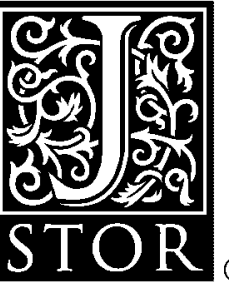

\section{Consistent Estimation of Cross-Sectional Models in Event Studies}

B. Espen Eckbo; Vojislav Maksimovic; Joseph Williams

The Review of Financial Studies, Vol. 3, No. 3. (1990), pp. 343-365.

Stable URL:

http://links.jstor.org/sici?sici=0893-9454\%281990\%293\%3A3\%3C343\%3ACEOCMI\%3E2.0.CO\%3B2-Z

Preemptive Bidding and the Role of the Medium of Exchange in Acquisitions

Michael J. Fishman

The Journal of Finance, Vol. 44, No. 1. (Mar., 1989), pp. 41-57.

Stable URL:

http://links.jstor.org/sici?sici=0022-1082\%28198903\%2944\%3A1\%3C41\%3APBATRO\%3E2.0.CO\%3B2-3

\section{A Theory for the Choice of Exchange Medium in Mergers and Acquisitions}

Robert G. Hansen

The Journal of Business, Vol. 60, No. 1. (Jan., 1987), pp. 75-95.

Stable URL:

http://links.jstor.org/sici?sici=0021-9398\%28198701\%2960\%3A1\%3C75\%3AATFTCO\%3E2.0.CO\%3B2-E

The Economic Effects of Federal and State Regulations of Cash Tender Offers

Gregg A. Jarrell; Michael Bradley

Journal of Law and Economics, Vol. 23, No. 2. (Oct., 1980), pp. 371-407.

Stable URL:

http://links.jstor.org/sici?sici=0022-2186\%28198010\%2923\%3A2\%3C371\%3ATEEOFA\%3E2.0.CO\%3B2-5

\section{The Market for Corporate Control: The Empirical Evidence Since 1980}

Gregg A. Jarrell; James A. Brickley; Jeffry M. Netter

The Journal of Economic Perspectives, Vol. 2, No. 1. (Winter, 1988), pp. 49-68.

Stable URL:

http://links.jstor.org/sici?sici=0895-3309\%28198824\%292\%3A1\%3C49\%3ATMFCCT\%3E2.0.CO\%3B2-E

\section{Life After Takeover}

David J. Ravenscraft; F. M. Scherer

The Journal of Industrial Economics, Vol. 36, No. 2. (Dec., 1987), pp. 147-156.

Stable URL:

http://links.jstor.org/sici?sici=0022-1821\%28198712\%2936\%3A2\%3C147\%3ALAT\%3E2.0.CO\%3B2-K

NOTE: The reference numbering from the original has been maintained in this citation list. 
http://www.jstor.org

\section{LINKED CITATIONS \\ - Page 5 of 5 -}

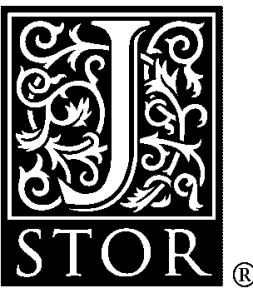

\section{The Hubris Hypothesis of Corporate Takeovers}

Richard Roll

The Journal of Business, Vol. 59, No. 2, Part 1. (Apr., 1986), pp. 197-216.

Stable URL:

http://links.jstor.org/sici?sici=0021-9398\%28198604\%2959\%3A2\%3C197\%3ATHHOCT\%3E2.0.CO\%3B2-8

Corporate Takeover Bids, Methods of Payment, and Bidding Firms' Stock Returns Nickolaos G. Travlos

The Journal of Finance, Vol. 42, No. 4. (Sep., 1987), pp. 943-963.

Stable URL:

http://links.jstor.org/sici?sici=0022-1082\%28198709\%2942\%3A4\%3C943\%3ACTBMOP\%3E2.0.CO\%3B2-Z

NOTE: The reference numbering from the original has been maintained in this citation list. 